\title{
The influence of age on apoptotic and other mechanisms of cell death after cerebral hypoxia-ischemia
}

\author{
C Zhu ${ }^{\star, 1,2,7}$, X Wang $^{1,2}, \mathrm{~F} \mathrm{Xu}^{1,2,7}, \mathrm{BA} \mathrm{Bahr}^{3}, \mathrm{M} \mathrm{Shibata}^{4}$, \\ $Y$ Uchiyama $^{4}, H_{\text {Hagberg }}{ }^{1,5}$ and K Blomgren ${ }^{1,6,7}$ \\ 1 Department of Physiology, Göteborg University, Göteborg, Sweden \\ 2 Department of Pediatrics, The Third Affiliated Hospital of Zhengzhou \\ University, Zhengzhou, PR, China \\ ${ }^{3}$ Department of Pharmaceutical Sciences and the Neurosciences Program, \\ University of Connecticut, Storrs, CT, USA \\ ${ }^{4}$ Department of Cell Biology and Neuroscience, Osaka University Graduate \\ School of Medicine, Osaka, Japan \\ ${ }^{5}$ Department of Obstetrics and Gynecology, Sahlgrenska University Hospital, \\ Göteborg, Sweden \\ ${ }^{6}$ Department of Pediatrics, The Queen Silvia Children's Hospital, Göteborg, \\ Sweden \\ 7 Present address: Arvid Carlsson Institute of Neuroscience at the Institute of \\ Clinical Neuroscience, Göteborg University, Box 432, SE 40530 Göteborg, \\ Sweden \\ * Corresponding author: C Zhu, Department of Physiology, Perinatal Center, \\ Göteborg University, Box 432, SE 40530 Göteborg, Sweden. \\ Tel: + 46317733539 ; Fax: + 46317733512 ; \\ E-mail: changlian.zhu@fysiologi.gu.se
}

Received 11.8.04; revised 01.10.04; accepted 01.10.04; published online 10.12.04 Edited by L Greene

\section{Abstract \\ Unilateral hypoxia-ischemia (HI) was induced in C57/BL6 male mice on postnatal day (P) 5, 9, 21 and 60 , corresponding developmentally to premature, term, juvenile and adult human brains, respectively. HI duration was adjusted to obtain a similar extent of brain injury at all ages. Apoptotic mechanisms (nuclear translocation of apoptosis-inducing factor, cyto- chrome $c$ release and caspase- 3 activation) were several-fold more pronounced in immature than in juvenile and adult brains. Necrosis-related calpain activation was similar at all ages. The CA1 subfield shifted from apoptosis-related neuronal death at P5 and P9 to necrosis-related calpain activation at P21 and P60. Oxidative stress (nitrotyrosine formation) was also similar at all ages. Autophagy, as judged by the autophago- some-related marker LC-3 II, was more pronounced in adult brains. To our knowledge, this is the first report demonstrating developmental regulation of AIF-mediated cell death as well as involvement of autophagy in a model of brain injury. \\ Cell Death and Differentiation (2005) 12, 162-176. \\ doi:10.1038/sj.cdd. 4401545 \\ Published online 10 December 2004}

Keywords: apoptosis-inducing factor (AIF); autophagy; caspase; calpain; cytochrome $c$; nitrotyrosine; hypoxia-ischemia; brain development

Abbreviations: $A B C$, avidin-biotin peroxidase complex; $A M C$, aminomethylcoumarin; AIF, apoptosis-inducing factor; Cyt $C$, cytochrome $c$; DTT, dithiothretitol; FBDP, alpha-fodrin breakdown product; HI, hypoxia-ischemia; LC3, microtubule-associated protein 1 light chain 3; MAP-2, microtubule-associated protein-2; NOS, nitric oxide synthase; NO, nitric oxide; $\mathrm{P}$, postnatal day; PBS, phosphate-buffered saline; TBS, trisbuffered saline.

\section{Introduction}

The extent of hypoxic-ischemic $(\mathrm{HI})$ injury depends on the degree of maturation of the brain as well as on the severity and duration of the insult. ${ }^{1-7}$ It is generally accepted that neurons in the immature brain tolerate a longer period of oxygen deprivation and/or ischemia than those in the adult brain. ${ }^{1,3}$ However, there are conflicting reports, showing that the immature brain is less resistant to $\mathrm{HI}$ brain damage than its adult counterpart. ${ }^{4}$ This is supported by other studies after $\mathrm{HI}$ or excitotoxic injury. ${ }^{8,9}$ Furthermore, clinical data suggest that outcome and mortality after acute brain injury are age dependent, with more severe injuries in infants than in adults. ${ }^{8,10}$

Cell death is usually classified as apoptotic or necrotic based on biochemical and morphological criteria, ${ }^{11,12}$ even though recent data suggest that mixed morphological phenotypes are frequently observed after ischemic insults. ${ }^{12-14}$ Necrotic cell death is a pathological process resulting from tissue damage and loss of energy. Apoptosis is a genetically controlled cell death that was initially recognized for its role in development. In some brain regions, more than half of the neurons die by apoptosis during brain development. ${ }^{15}$ Many apoptosis-related factors have been demonstrated to be upregulated in the immature brain, such as caspase-3, Apaf-1, Bcl-2 and Bax. ${ }^{16-19}$ Activation of apoptotic mechanisms contributes to the pathogenesis of brain damage in acute neuropathological disorders, such as $\mathrm{HI}$, particularly in the immature brain. ${ }^{1,14,16,20-25}$ Autophagy is another type of cell death mechanism with distinct morphological features whereby lysosome-mediated engulfment of injured cells or cellular fragments can occur. ${ }^{26}$ It seems clear that, depending on the developmental level of the brain at the time of injury, different cell types and regions will be injured, at different rates, and different mechanisms of injury will be activated. ${ }^{1,3,22,27,28}$ Understanding the nature of cell death after $\mathrm{HI}$ at different developmental stages is essential to be able to choose effective therapeutic targets, ${ }^{29,30}$ and since these vary during development, prevention and treatment of brain injury need to be adjusted accordingly. To better understand the mechanisms and developmental variations of $\mathrm{HI}$ neuronal cell death, we developed a mouse model where a similar extent of injury could be achieved by adjusting the duration of the hypoxia time, 
thereby enabling us to study the relative contribution of different mechanisms at different ages. Specifically, we investigated caspase-dependent and caspase-independent apoptotic mechanisms as well as one marker of oxidative stress (NOS-dependent, peroxynitrite-mediated nitrotyrosine formation), necrosis-related activation of calpains and autophagy.

\section{Results}

\section{HI brain injury}

Similar tissue injury was seen in the cortex, striatum, hippocampus and thalamus in the ipsilateral hemisphere at all ages (Figure 1a). The nucleus habenularis $(\mathrm{NH})$, however displayed a marked developmental change in its susceptibility to $\mathrm{HI}$. The $\mathrm{NH}$ is very sensitive to $\mathrm{HI}$ in the immature brain, ${ }^{31}$ but this vulnerability decreased with age and the $\mathrm{NH}$ was resistant to $\mathrm{HI}$ in $\mathrm{P} 60$ mice (Figure 1b). The neuropathological score and tissue loss were virtually identical at P5, P9, P21 and P60 using the different durations of hypoxic exposure indicated in Materials and Methods (Figure 1c).

\section{Apoptosis-inducing factor (AIF) translocation and cytochrome $c$ (Cyt $c$ ) release from mitochondria after $\mathrm{HI}$}

The levels of AIF protein in mouse brain homogenates were virtually unchanged during normal brain development from P5 to P60 (Figure 2a). In the mitochondrial fraction, there was about $20 \%$ less AIF in the ipsilateral hemisphere compared with the contralateral hemisphere in $\mathrm{P} 5$ mice $24 \mathrm{~h}$ post-HI, indicating that this amount had been released. This AIF release was reduced to about $10 \%$ in juvenile and adult brains (Figure 2b). In tissue sections, AIF immunoreactivity was nonnuclear in normal neurons; however, in damaged brain areas, as judged by the loss of MAP-2, AIF was translocated from mitochondria to nuclei very early after $\mathrm{HI}$, producing a distinct nuclear staining (Figure 2c), in agreement with our earlier findings in the neonatal rat brain after $\mathrm{HI}^{32}$ in the adult mouse brain after focal ischemia ${ }^{33}$ and in progenitor cells of the developing brain after irradiation. ${ }^{34}$ The number of AIFpositive nuclei increased significantly at $3 \mathrm{~h}$ post-HI and reached a peak at $24 \mathrm{~h}$ after the insult in most regions of the immature brain, more pronounced in P5 mice (Figure 3). Significant, but much fewer, AIF-positive nuclei were a

P5

P9

Hippocampus

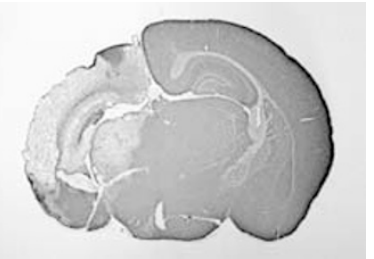

P21

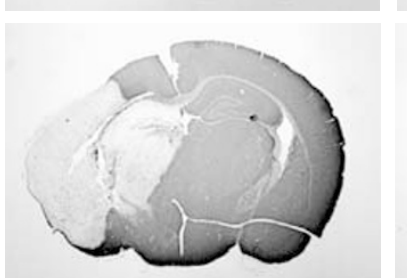

1

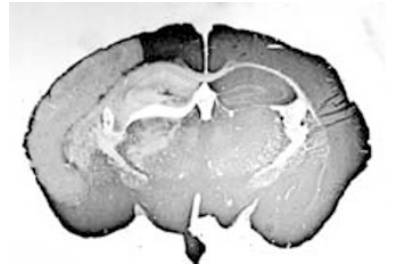

P60

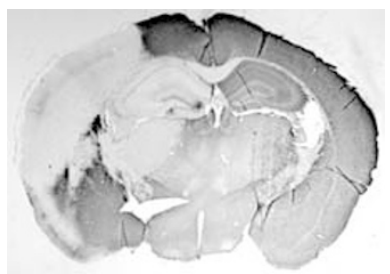

Striatum
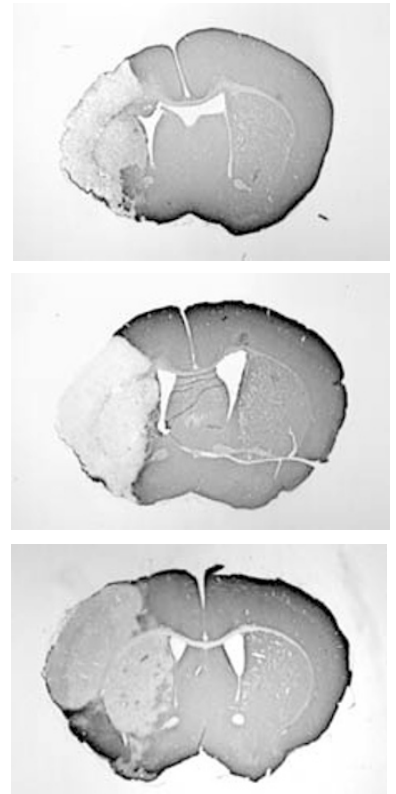

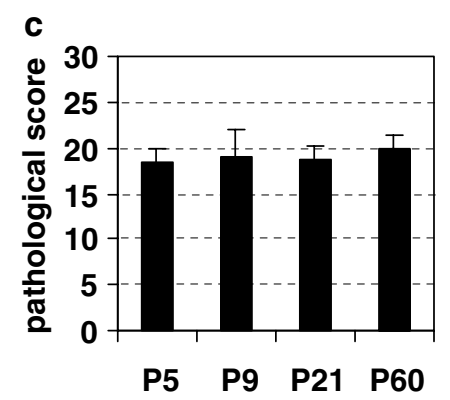

b
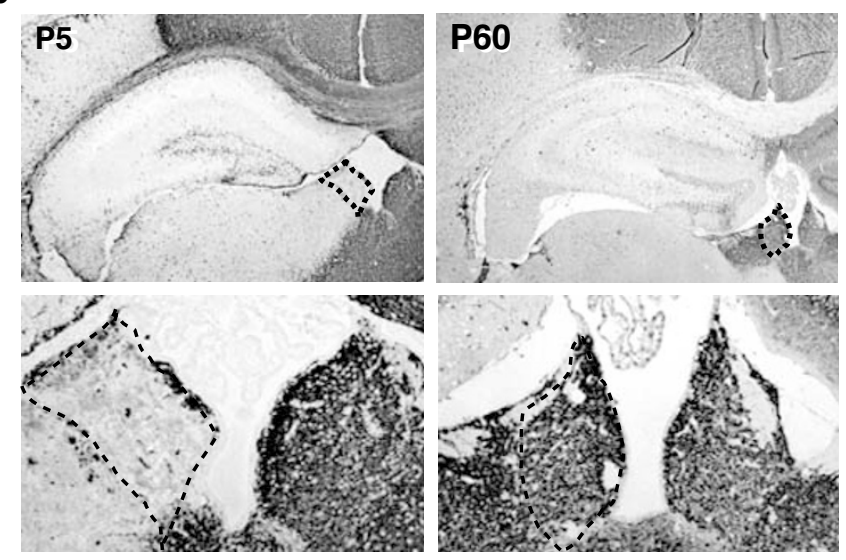

Figure 1 Brain injury after $\mathrm{HI}$ in the developing brain. (a) Representative MAP-2 staining $72 \mathrm{~h}$ after $\mathrm{HI}$ at the dorsal hippocampus and striatum levels of P5, P9, $\mathrm{P} 21$ and P60 mice after 65, 60, 50 and 40 min hypoxia, respectively. The injury encompassed large areas of the cortex, hippocampus, striatum and thalamus. (b) The sensitivity of the $\mathrm{NH}$ to $\mathrm{HI}$ was very different in the immature (P5) brain and adult (P60) brains. This area is very vulnerable in P5 brains but there was no obvious injury in the adult brains as indicated by MAP-2 staining $24 \mathrm{~h}$ post-HI. The dotted areas are shown in a larger magnification in the lower panels. (c) The brain injury was similar between different age groups as evaluated by the pathological score (left graph) and tissue loss (right graph) ( $n=6$ for each age group) 
a
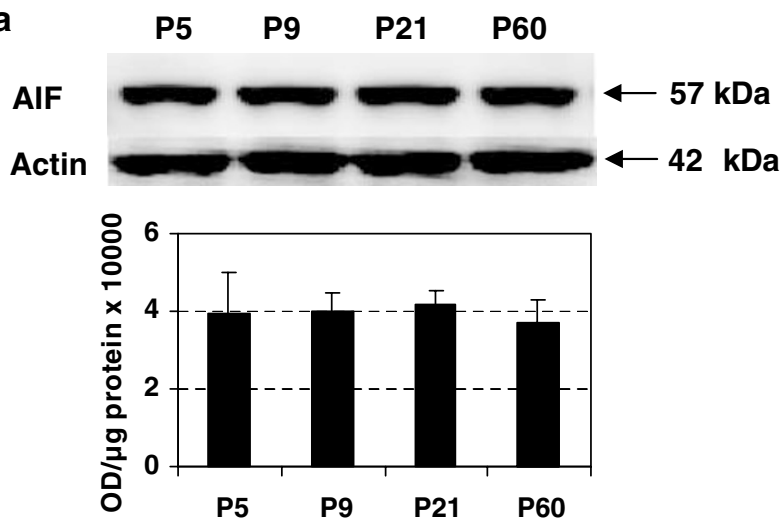

b $\frac{\mathrm{P5}}{\mathrm{CL} \mathrm{IL}} \frac{\mathrm{P9}}{\mathrm{CL} I \mathrm{IL}} \frac{\mathrm{P} 21}{\mathrm{CL} \mathrm{IL}} \frac{\mathrm{P} 60}{\mathrm{CL} \text { IL }}$ Actin

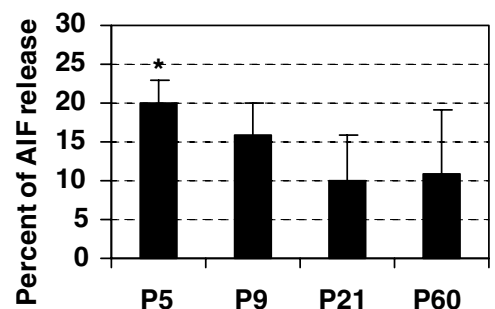

c

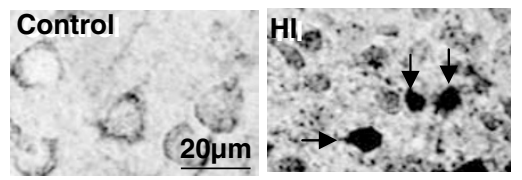

Figure 2 Developmental regulation of AIF. (a) Immunoblots of normal brain homogenate samples from postnatal day (P) $5,9,21,60$ ( $n=5$ for each age), demonstrating that there was no significant change in the AIF protein levels during normal development. The actin staining on the same membrane verified equal loading. (b) AIF was released from the mitochondrial fraction in the ipsilateral (IL) compared with the contralateral (CL) hemispheres at $24 \mathrm{~h}$ post- $\mathrm{HI}$. The loss of AIF was more pronounced in the immature brains $\left({ }^{*} P<0.05\right.$ compared with P21 and P60). The actin staining on the same membrane verified equal loading. (c) Typical AIF immunostaining of control and injured (HI) tissue. Injured cells displaying nuclear AIF staining are indicated by arrows. Bar $=20 \mu \mathrm{m}$

observed in the mature mouse brain regions (except for the denate gyrus (DG)), especially in P60 mice. In the $\mathrm{NH}$, the number of AIF-positive nuclei decreased dramatically with development reflecting the resistance to $\mathrm{HI}$ at P21 and P60 (Figure 3).

Another mitochondrial, proapoptotic protein, Cyt $c$, displayed an approximately two-fold increase during normal brain development (Figure 4a). It was released from mitochondria in the ipsilateral hemisphere after HI, more pronounced in the immature brain than in the adult brain (Figure $4 b$ ). In tissue sections, neuronal Cyt $c$ staining was found to be more intense and distinct in the cytosol of damaged brain areas (Figure 4c), presumably indicating release of Cyt $c$ from mitochondria, as demonstrated ear- lier. ${ }^{32,33}$ Counting of cells with strong cytoplasmic Cyt $c$ staining, revealed a pattern similar to that of AIF-positive nuclei, with higher numbers in the immature brains, but the total number of strongly Cyt $c$ staining cells was smaller than that of AIF-positive nuclei (Figure 5).

\section{Caspase-3 activation after $\mathrm{HI}$}

Caspase-3, the most abundant effector caspase in the immature brain, decreased dramatically with brain maturation (Figure 6a), displaying an inverse correlation with Cyt $c$, as demonstrated earlier in the rat brain. ${ }^{16,32}$ The $32 \mathrm{kDa}$ proform was cleaved and produced the calpain-dependent $29 \mathrm{kDa}$ and the caspase-dependent active $17 \mathrm{kDa}$ fragments after $\mathrm{HI}$ in the ipsilateral hemisphere in the immature brains. The cleavage products were difficult to detect in the juvenile and adult brains (Figure 6b). Using an antibody against the $17 \mathrm{kDa}$ active form of caspase-3 on tissue sections, conspicuous staining was obtained in numerous neurons in MAP-2negative areas in the immature brains (Figure 6c), and this staining has earlier been shown to colocalize with other markers of cellular injury. ${ }^{16,21,32}$ DEVDase assays showed that the caspase-3-like activity increased 31 -fold in P5 and 25fold in $\mathrm{P} 9$ mice $24 \mathrm{~h}$ post-HI, compared with the normal control brains (Figure 6b), consistent with when the peak of caspase3 activation occurs in the neonatal rat brain after $\mathrm{HI}^{16,23}$ Caspase- 3 activity increased about $40 \%$ in P21 and P60 mice, compared with the normal control brains (Figure 6d). Active caspase- 3 staining in tissue sections increased at $3 \mathrm{~h}$ and reached a peak at $24 \mathrm{~h}$ post-HI in most regions in the immature and juvenile brains (P5, P9 and P21) (Figure 7). In the adult brains (P60), the caspase-3-positive cells appeared gradually and reached a peak at $72 \mathrm{~h}$ in all injured areas (Figure 7). The total number of active caspase-3-positive cells was lower in the juvenile and adult brains than in the immature brains, except for the CA3 (P21 and P60) and DG (P21) subfields of the hippocampus (Figure 7).

\section{Calpain activation after $\mathrm{HI}$}

Calpain 1 did not change appreciably in the normal brains during development (Figure 8a), but after $\mathrm{HI}$ almost half of the calpain 1 was lost in the immature brains (Figure 8b), most likely as a result of activation and subsequent degradation. ${ }^{35}$ In the juvenile and adult brains, however, the loss was significantly lower, only about 5\% in P60 mice (Figure 8b). Calpain 2 was not significantly regulated during development, except for a somewhat higher level in P5 mice (Figure 8c). About $20-30 \%$ of the calpain 2 protein was lost after $\mathrm{HI}$, but there was no significant difference between ages (Figure 8d). Activation of calpains results in specific fodrin cleavage products, alpha-fodrin breakdown product (FBDP), of 145 and $150 \mathrm{kDa}$, relatively resistant to further degradation. FBDPs have been used extensively as markers of calpain activation, including after neonatal $\mathrm{HI} .{ }^{16,31,35-37}$ In this study, FBDPs were prominent after $\mathrm{HI}$ at all ages (Figure $8 \mathrm{e}$ ), unlike the caspase-dependent $120 \mathrm{kDa}$ cleavage product, which was apparent only in P5 and P9 mice (Figure 8e). In tissue sections, an antibody specific for the $n$-terminal $145 \mathrm{kDa}$ FBDP, produced strong staining in injured neurons early after 

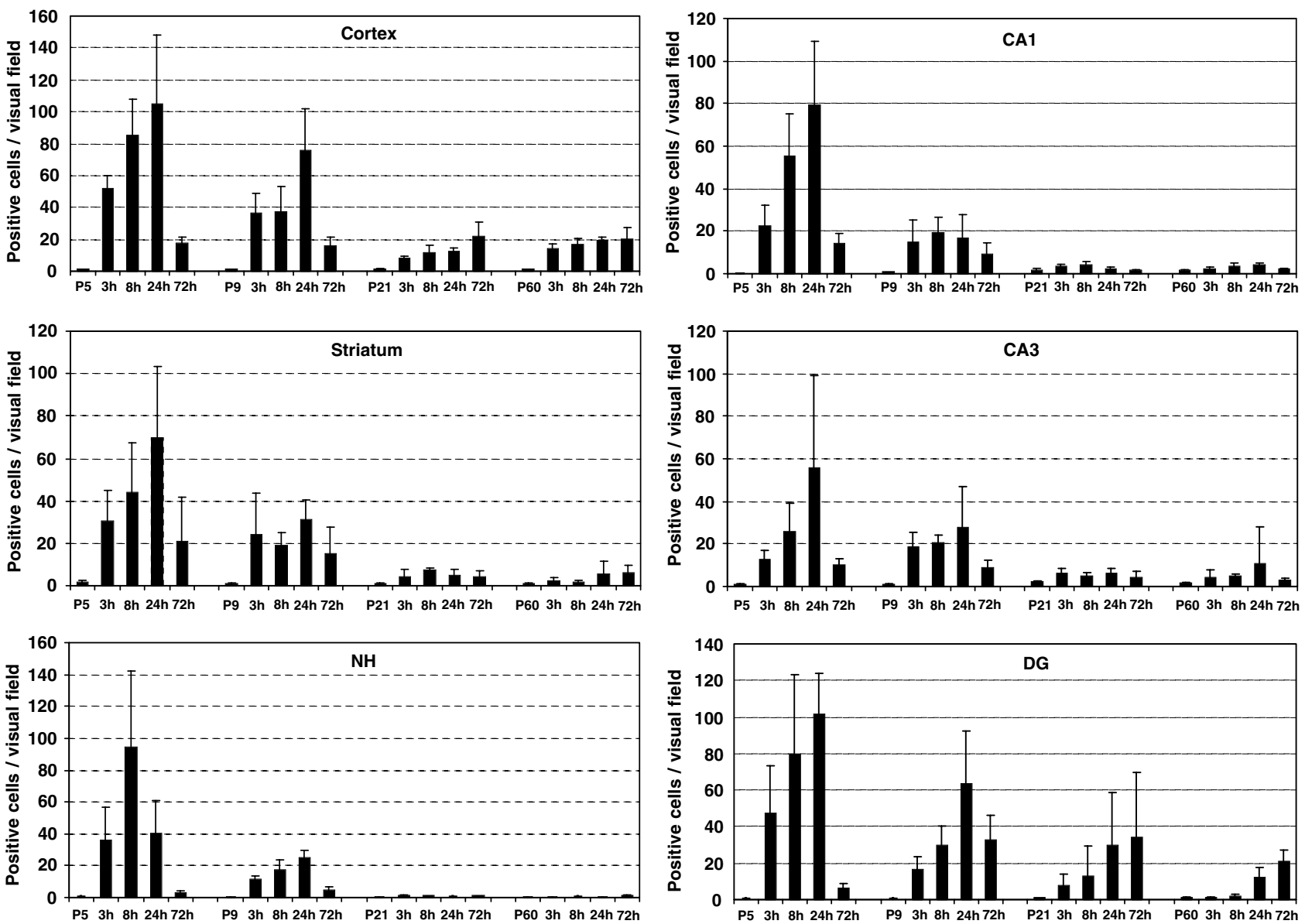

Figure 3 Counts of AIF-positive cells in the ipsilateral hemisphere after HI. AIF-positive cells (as shown in Figure 2c) displayed conspicuous cytosolic and/or nuclear immunostaining. Cells were counted in the cortex, striatum, the NH of the thalamus and the CA1, CA3 as well as DG of the hippocampus. Data are presented as mean \pm s.d ( $n=6$ animals per time point). The patterns of AIF immunostaining appeared to follow the time course for development of injury in the selected brain regions for P5 and P9, but not for P21 and P60. The number of AIF-positive cells in the cerebral cortex peaked at $24 \mathrm{~h}$ post-HI for both P5 and P9 mice, but there was no dramatic increase in AIF-positive cells in the injured areas of P21 and P60 mice. The lack of AlF-positive cells in the NH of P21 and P60 mice reflects the lack of injury in this region at these ages

HI (Figure 8f). FBDP-positive cells accumulated and reached a peak in injured and borderline regions ipsilaterally as early as $3 \mathrm{~h}$ post- $\mathrm{HI}$ in the cortex, striatum and $\mathrm{NH}$ of $\mathrm{P} 5$ mice (Figure 9). FBDP-positive cells appeared in a somewhat delayed fashion in P60 mice in those regions (Figure 9). In the hippocampus, especially in the CA1, unlike the cortex, very few FBDP-positive cells could be detected in P5 and P9 animals, but more positive cells were observed in P21 and P60 animals (Figure 9).

\section{Nitrotyrosine formation after $\mathrm{HI}$}

Both nNOS and iNOS showed a similar developmental pattern, displaying approximately three-fold higher protein levels at P5 than P60 (Figure 10a and b). In tissue sections, NOS-dependent, peroxynitrite-mediated nitrotyrosine immunoreactivity was mainly located in the nuclei of injured cells (Figure 10c). The number of nitrotyrosine-positive cells increased immediately after $\mathrm{HI}$ and reached a peak around $8-24 \mathrm{~h}$ in most of the brain regions (Figure 11), as described earlier in the neonatal rat brain. ${ }^{38}$ The number of nitrotyrosine-positive cells did not vary appreciably between the different ages (Figure 11). The lack of staining in the $\mathrm{NH}$ reflected its resistance to $\mathrm{HI}$, as in the case of all the other stainings. The only injured area that displayed a developmental difference was the DG, having fewer positive cells in the juvenile and adult brains (Figure 11).

\section{Autophagy after HI}

Immunoblots of homogenates using an antibody against microtubule-associated protein 1 light chain 3 (LC3) showed that LC3-I (16 kDa) was abundant in the brain. LC3-I is cytosolic, whereas LC3-II (14 kDa) is membrane-bound, and the amount of LC3-II is correlated with the extent of autophagosome formation. ${ }^{26}$ Both LC3-I and LC3-II could be detected in normal control brains, more pronounced in the immature brains, and both forms were significantly lower in normal adult brains (Figure 12a). After HI, LC3-II increased in the ipsilateral hemisphere, and this process appeared to peak 24-72 $\mathrm{h}$ after $\mathrm{HI}$ (data not shown). The relative increase of LC3-II in the ipsilateral hemisphere was more pronounced in the adult than the immature brain, approximately three-fold 

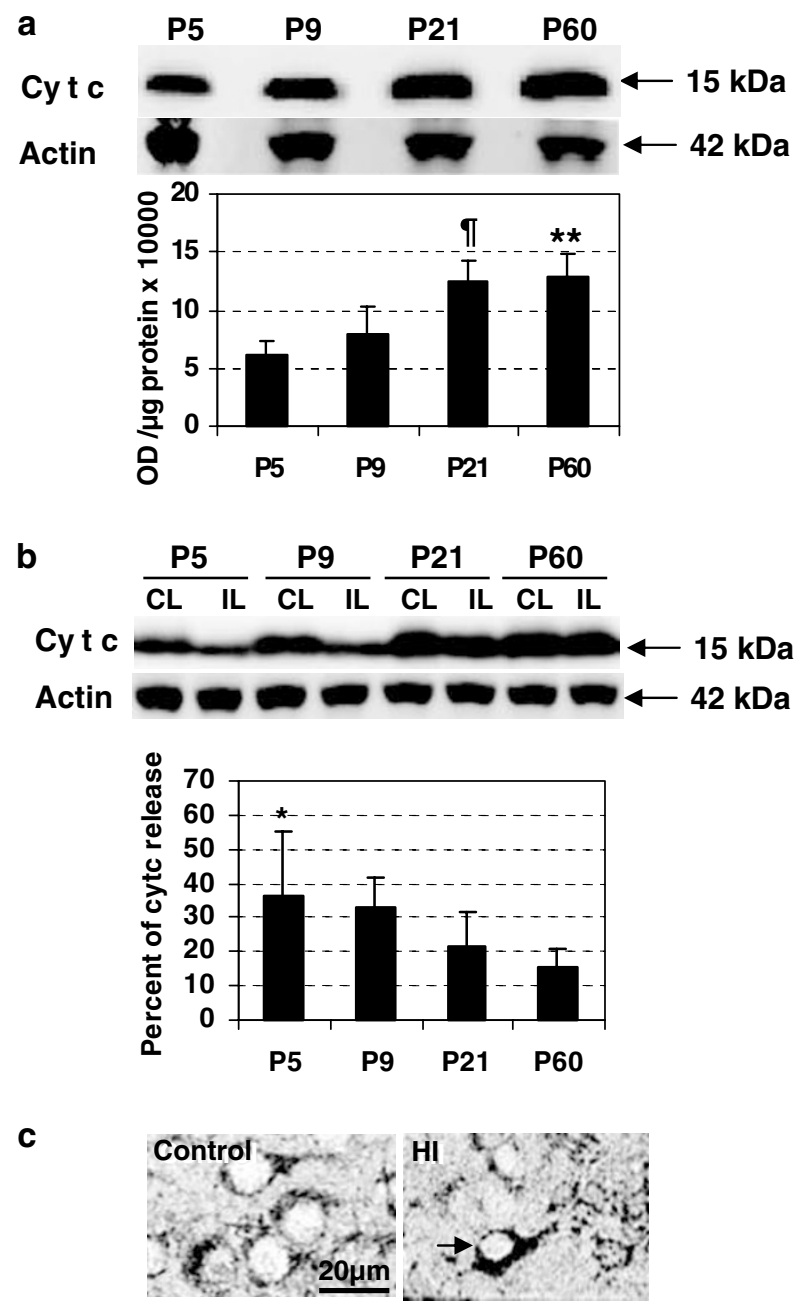

Figure 4 Cyt $c$ release from mitochondria after $\mathrm{HI}$. (a) The top panel shows representative immunoblots of homogenate samples stained with an antibody against Cyt $c$. The middle panel shows equal loading by actin staining. The lower panel shows the results from densitometric quatifications, demonstrating that Cyt $c$ increased significantly during development $\left({ }^{\star \star} P<0.01\right.$ and $\uparrow P<0.01$ compared with P5 and P9). (b) Cyt $c$ was released from the mitochondrial fraction after $\mathrm{HI}$ in the ipsilateral $(\mathrm{IL})$ compared with the contralateral $(\mathrm{CL})$ hemisphere at $24 \mathrm{~h}$ post- $\mathrm{Hl}$, more pronounced in the immature brains $\left({ }^{*} P<0.05\right.$ compared with $\mathrm{P} 60$ ). The actin staining on the same membrane verified equal loading. (c) Typical immunostaining of Cyt $c$ in control and postischemic $(\mathrm{HI})$ tissue. An injured, Cyt $c$-positive cell is indicated by an arrow in the right panel. $\mathrm{Bar}=20 \mu \mathrm{m}$

higher compared with normal controls, somewhat less compared with the contralateral hemispheres (Figure 12b).

\section{Discussion}

\section{The influence of age on HI brain injury}

The developing brain has been reported to be more resistant to certain insults than its adult counterparts. ${ }^{1,3}$ The reason for increased susceptibility to injurious stimuli in older brains is often attributed to increased metabolic requirements once connectivity is complete. ${ }^{39}$ Other experimental studies question these conclusions. ${ }^{4,8,9,40} \mathrm{McDonald}^{\text {et }}$ al. ${ }^{8}$ injected NMDA into the striatum of 7-day- and 3-month-old rats, producing 21 times larger damage in the younger animals than in the adults, ${ }^{8}$ which reflects the higher density of NMDA receptors in the developing brain. Similarly, Ikonomidou et al. ${ }^{9}$ demonstrated that the vulnerability to $\mathrm{HI}$ peaked at $\mathrm{P} 6$, and diminished thereafter. Yager et al., using male rats exposed to identical $\mathrm{HI}$ insults, demonstrated that brain damage was most severe in 1- and 3-week-old animals, followed by those that were 6 months old. The 6- and 9-week-old animals had significantly less injury than the other age groups. ${ }^{4}$ Our results are consistent with the apprehension that immature brains are considerably less susceptible to $\mathrm{HI}$ injury than mature ones. The two independent methods used to evaluate brain injury in this study have been shown to correlate well with each other. ${ }^{41-43}$ Our results showed that longer hypoxia times were required to obtain a similar degree of brain injury in the immature brains than in the older ones. Furthermore, in the immature brain, extensive atrophy was observed, that is, in addition to the acute loss of dead tissue, there was secondary loss of tissue because the acutely lost tissue could not support the further growth of the surrounding brain tissue. Using the different durations of hypoxia, both the extent and distribution of brain injury was very similar, with a couple of exceptions. The $\mathrm{NH}$ was virtually resistant to $\mathrm{HI}$ injury in $\mathrm{P} 60$ mice, whereas in the immature brain, this area is one of the first to display signs of tissue damage, such as loss of MAP-2. The $\mathrm{CA} 1$ has earlier been reported to be relatively resistant to $\mathrm{HI}$ in the immature brain, and the selective vulnerability of this subfield developed between P13 and P21 in rats. ${ }^{3}$ In the present study, the CA1 was injured at all ages; however, the mechanisms involved appeared to change dramatically between P5 and P21, shifting from mainly AIF translocation, Cyt $c$ release and caspase- 3 activation at $P 5$, to mainly calpain activation at P21 and P60. It is clear that the vulnerability of the brain is strongly influenced by age, although the mechanisms behind these developmental changes are only partly understood..$^{2,9,22,44}$

\section{The influence of age on cell death mechanisms}

Activation of caspase-3 appears to be a critical event in the execution of neuronal apoptosis in the brain during development and after acute injury. ${ }^{1,21,23-25}$ In this study, we examined caspase-3 during normal development and after HI. We demonstrated that caspase-3 decreased dramatically during normal development of the mouse brain as judged by the basal activity and by immunoblotting, consistent with our previous reports from the rat brain. ${ }^{16,23,32}$ This developmental downregulation of caspase-3, as well as downregulation of other elements involved in caspase- 3 activation, such as Apaf-1 and bax, occurs in parallel with the decline of physiological programmed cell death and may serve as a supplementary mechanism protecting the mature brain from apoptosis. ${ }^{17,18,40}$ Accordingly, caspase-3 activity increased dramatically after $\mathrm{HI}$ in the immature brain but increased only slightly in the mature brain. Immunostaining of active caspase-3 showed very few positive cells in most regions of the adult brain, indicating that caspase-3-mediated neuronal death does not play a major role in the mature brain after $\mathrm{HI}$, in accordance with earlier findings. ${ }^{1,27}$ In support of our findings, 

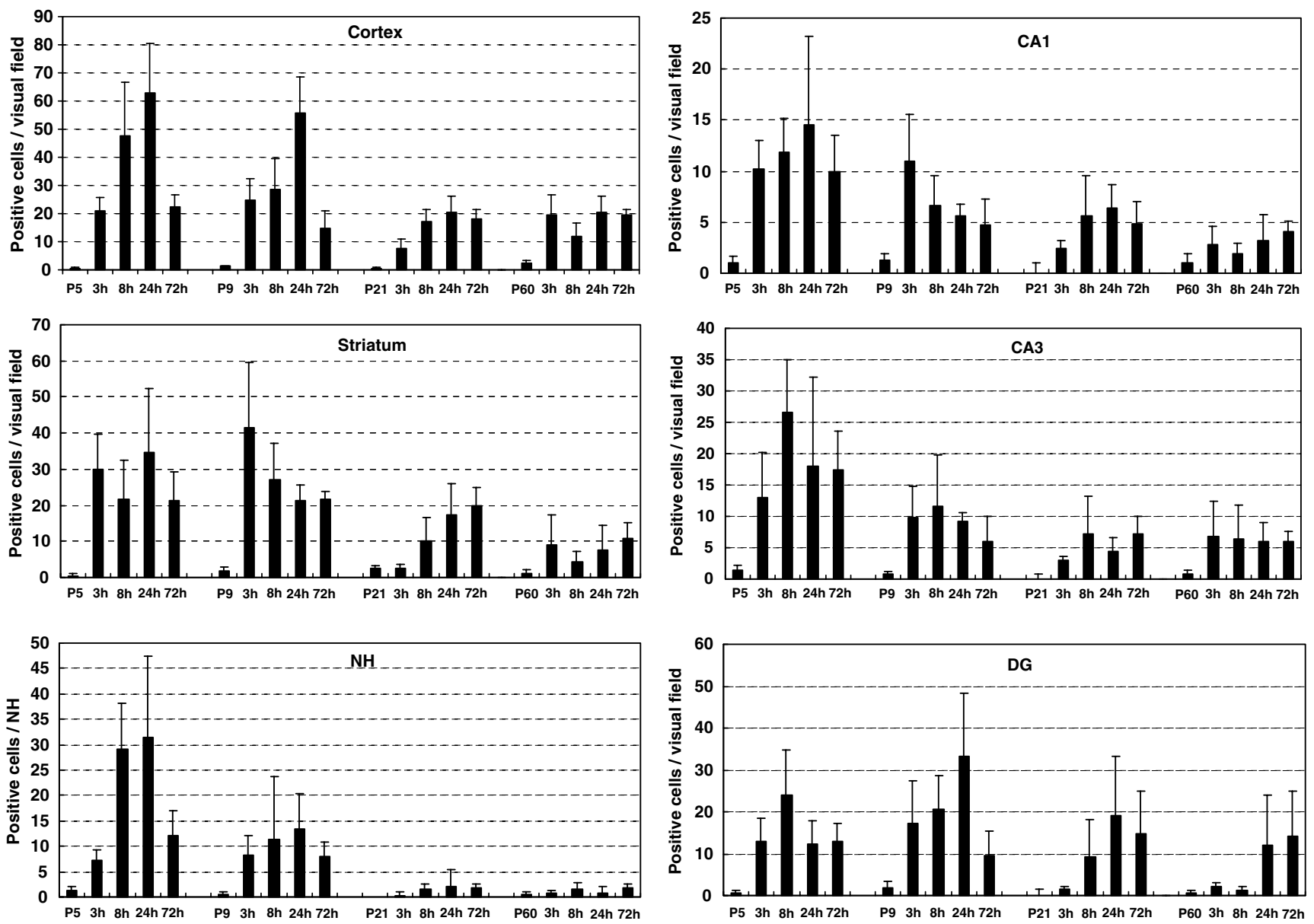

Figure 5 Counts of Cyt c-positive cells in the ipsilateral hemisphere after $\mathrm{HI}$. Cyt c-positive cells were counted in six different regions as in Figure 3 . The total number of positive cells was higher after $\mathrm{HI}$ in the younger animals (P5, P9) in most of the regions, displaying a pattern similar to that of the AlF counts in Figure 3

Pohl et al. ${ }^{45}$ found a marked decrease with age in the extent of distant, apoptosis-related cell death after traumatic brain injury.

Cyt $c$ is an essential component of the respiratory chain, an ATP-generating system in the inner mitochondrial membrane. We found that the relative content of Cyt $c$ increased during brain development, in agreement with earlier findings. ${ }^{32,46}$ This fits with the increased energy requirement in the mature brain needed to maintain the elaborate network of axons and dendrites. Release of Cyt $c$ from mitochondria as a consequence of $\mathrm{HI}$ has been detected by immunoblotting and immunohistochemistry. ${ }^{32,47}$ In some of the affected cells, the staining was associated with DNA fragmentation suggesting apoptosis. ${ }^{32,48}$ Other studies showed that loss of mitochondrial Cyt $c$ was correlated with an increased production of reactive oxygen species by mitochondria, which may contribute to cellular damage. ${ }^{49,50}$ In this study, there were fewer cells displaying increased cytoplasmic Cyt $c$ staining in most regions of the mature brains than in the immature brains, indicating that Cyt $c$-related, caspase-3dependent apoptotic cell death in the mature brain is not as prevalent as in the immature brain.

Caspases have been recognized as important mediators of apoptotic cell death after $\mathrm{HI}$ brain injury. ${ }^{24}$ However, caspase inhibition has typically resulted in limited neuronal protection. $^{32,51}$ This indicates that additional or caspase-independent pathways of neuronal cell death exist. AIF was identified as a major player in caspase-independent cell death. ${ }^{52}$ Genetic targeting of AIF abolished the first wave of apoptosis that is indispensable for early embryonic morphogenesis. ${ }^{53}$ The expression of AIF in the normal rat brain was reported to decrease slightly with development. However, the protein expression in the cerebellum was markedly increased, distinctively different from the mRNA expression. ${ }^{54}$ In the normal rat brain, not including the cerebellum, we found no changes of total AIF protein during the normal brain development. ${ }^{32}$ In this study, similar results were found using the mouse brain. So, the constant levels of AIF and increasing levels of mitochondrial markers demonstrated a relative downregulation of AIF with age. ${ }^{32}$ Mitochondrial release and nuclear translocation of AIF correlating with neuronal apoptotic cell death have been demonstrated in different brain injury models. $^{32,33,54-58}$ In this study, the total number of AIFpositive nuclei decreased in all brain regions and at all the time points with increasing age after $\mathrm{HI}$, indicating that AIF plays a more important role in the early development of neuronal apoptosis. Blocking AIF function with neutralizing antibodies provided significant protection against neuronal cell death. ${ }^{59}$ 
Downregulation of AIF by RNA interference could inhibit UVAinduced cell death ${ }^{60}$ and oxygen/glucose deprivation-induced death of primary cultured neurons (authors' unpublished observations). AIF also has a potent oxidoreductase function $^{61}$ and the Harlequin mouse, expressing $80 \%$ lower levels of AIF, displayed increased amounts of hydroperoxides in the brain, cerebellum and heart. ${ }^{62}$ In summary, accumulating evidence suggests that AIF plays an important role both in normal development and under pathological conditions.

Calpains represent a class of cytosolic cysteine proteases activated by elevated intracellular calcium concentrations.

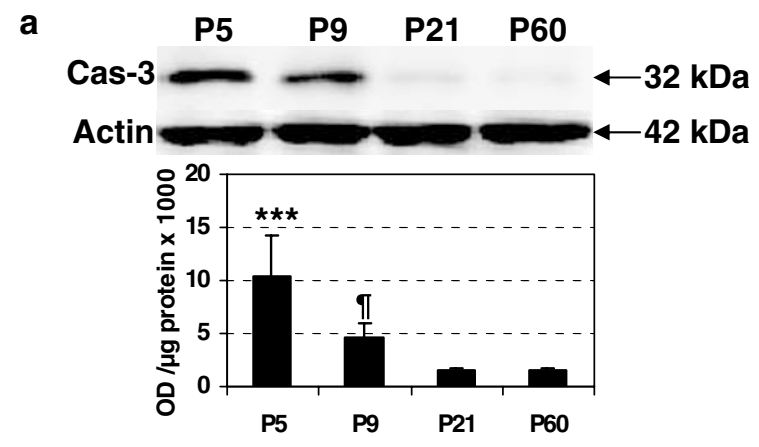

b
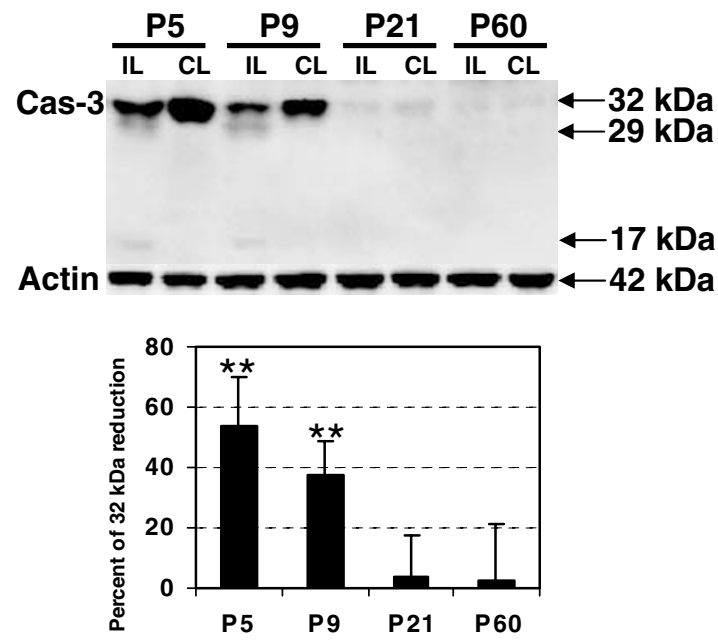

C
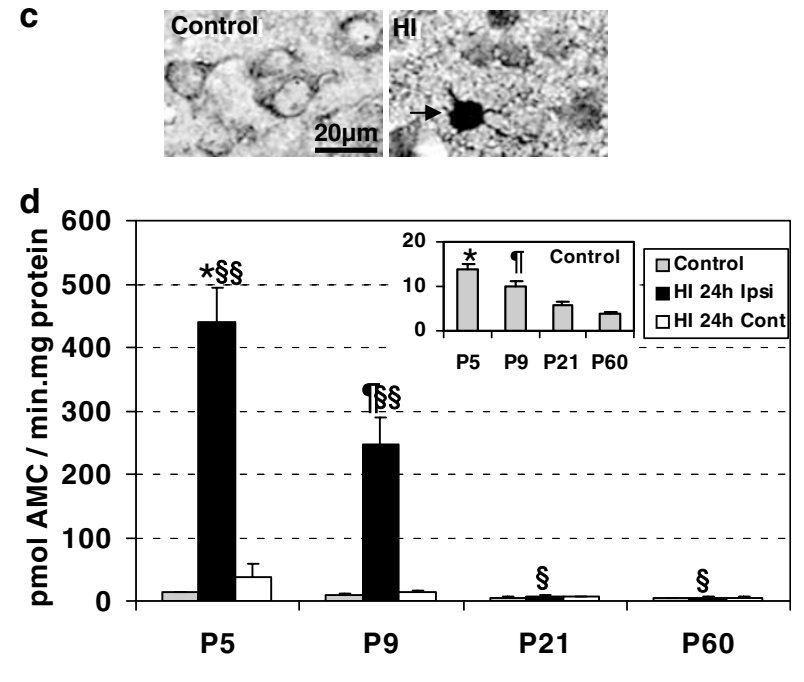

Under pathological conditions, calpains have been implicated in excitotoxic neuronal injury and $\mathrm{HI}$ brain injury. ${ }^{16,31,35-37,63,64}$ Calpains are activated early in situations of energy depletion and increased calcium influx, triggering other downstream events leading to neurodegeneration. Calpains are generally considered to be activated during excitotoxic and other necrosis-related conditions. ${ }^{65}$ Fodrin is a well-known calpain substrate and detection of specific FBDP has been widely used to detect calpain activity. ${ }^{16,36,37,63,66,67}$ In this study, FBDP-positive cells increased and reached a peak $3 \mathrm{~h}$ post-HI in the cortex, striatum and nucleus habenularis in the immature brain, probably indicating early, necrosis-related cell death. However, in the mature brain, the activation of calpains occurred later, as judged by the later-appearing FBDP, and remained on a high level even at $72 \mathrm{~h}$ postinsult, a time point by which there were almost no FBDP-positive cells left in any region of the immature brain. This may indicate sustained calpain activation resulting in lysosomal rupture, causing neuronal necrosis. ${ }^{68}$

Nitric oxide (NO) is produced by three isoforms of nitric oxide synthase (NOS). Inducible and neuronal NOS (iNOS and nNOS, respectively) activities have been demonstrated to increase in models of $\mathrm{HI}$ in the immature brain. ${ }^{69-71}$ Excessive $\mathrm{NO}$ produced after $\mathrm{HI}$ combines rapidly with superoxide to form the powerful oxidizing agent peroxynitrite $\left(\mathrm{ONOO}^{-}\right)$. The $\mathrm{ONOO}^{-}$adduct is freely diffusible in its protonated form, oxidizes thiol groups, damages mitochondrial respiration and induces protein nitrosylation. Nitrosylation of tyrosine residues in proteins yields the compound 3-nitrotyrosine, and immunohistochemical detection of nitrotyrosine can be used as an indicator of peroxynitrite formation after $\mathrm{HI}^{38}$ Pharmacological inhibition nNOS and iNOS reduced nitrotyrosine formation $^{38}$ and was demonstrated to be neuroprotective. ${ }^{72}$ Oxidative stress, including production of $\mathrm{NO}$ and peroxynitrite, is considered to induce mainly necrotic cell death but may also be involved in apoptosis. ${ }^{73}$ The developing brain may be

Figure 6 Caspase-3 activation after HI. (a) The $32 \mathrm{kDa}$ proform of caspase-3 decreased during development. There was no significant difference between P21 and P60. ( ${ }^{\star \star \star} P<0.001$ compared with P9, P21 and P60; $\uparrow P<0.001$ compared with P21 and P60.) The actin staining on the same membrane verified equal loading. (b) After HI, the proform was cleaved and produced 29 and $17 \mathrm{kDa}$ fragments in the ipsilateral (IL), but not in the uninjured contralateral $(\mathrm{CL})$, hemisphere in the P5 and P9 mice. Densitometric quantification showing the relative loss of the $32 \mathrm{kDa}$ proform demonstrated a greater decrease in the P5 and P9 brains $\left({ }^{* *} P<0.01\right.$ compared with P21 and P60). The actin staining on the same membrane verified equal loading. (c) Typical immunostaining of active caspase-3 c in control and postischemic (HI) tissue. An injured, active caspase-3positive cell is indicated by an arrow in the right panel. Bar $=20 \mu \mathrm{m}$. (d) Crude cytosolic fractions from naïve P5, P9, P21 and P60 ( $n=5$ for each age) control animals (Control), and from animals subjected to $\mathrm{HI}$, were assayed for their ability to cleave a fluorogenic peptide substrate (DEVD), reflecting the caspase-3-like activity. All animals subjected to $\mathrm{HI}$ were killed $24 \mathrm{~h}$ post-HI. The data represent the average from five male animals in each group \pm S.D. The activity decreased significantly during development in the normal, control brains (small panel) $\left({ }^{\star} P<0.0001\right.$ compared with $\mathrm{P} 9, \mathrm{P} 21, \mathrm{P} 60 ; \uparrow P<0.001$ compared with $\mathrm{P} 21$, $\mathrm{P} 60)$. After $\mathrm{HI}$, the activity increased significantly at $24 \mathrm{~h}$ post-HI in all the groups in the ipsilateral (Ipsi) compared with normal controls, much more pronounced for P5 (31-fold increase) and P9 mice (25-fold increase). The increase was not nearly as pronounced in $P 21$ and $P 60$ mice $(\$ \S P<0.0001$ and $\S P<0.05$ compared with the normal controls in the same age group; ${ }^{*} P<0.0001$, compared with $\mathrm{P} 9, \mathrm{P} 21, \mathrm{P} 60 ; \uparrow P<0.001$, compared with $\mathrm{P} 21, \mathrm{P} 60)$ 

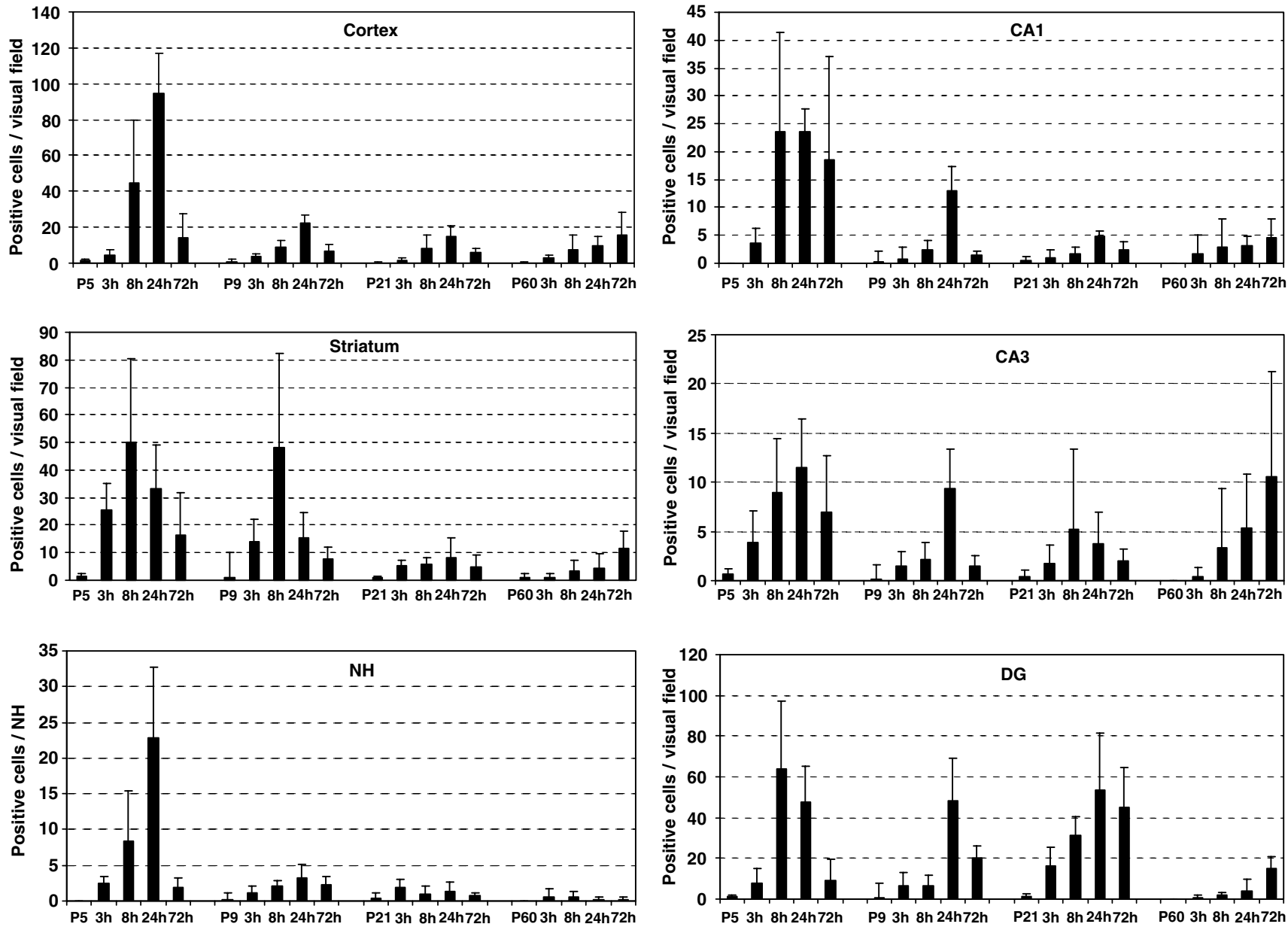

Figure 7 Counts of active caspase-3-positive cells in the ipsilateral hemisphere after HI. Active caspase-3-positive cells were counted in six different regions as in Figures 3 and 5 . In most regions, the number of caspase-3-positive cells increased from $3 \mathrm{~h}$ and reached a peak at $24 \mathrm{~h}$ in the cortex of P5, P9 and P21 animals, but at $72 \mathrm{~h}$ for P60 mice

particularly vulnerable to oxidative damage because of its high concentrations of unsaturated fatty acids, high rate of oxygen consumption, low concentrations of antioxidants, and increased availability of 'free' redox-active iron. ${ }^{74}$ In this study, however, the extent of nitrotyrosine formation after $\mathrm{HI}$ was similar at all ages, despite downregulation of both nNOS and iNOS protein during development. Notably, the levels of iNOS were constitutively high in the immature brain even in naïve control animals.

Autophagy is a process responsible for the bulk degradation of intracellular material in double or multiple-membrane autophagic vesicles, and their delivery to and subsequent degradation by the cell's own lysosomal system. Just like the genetically controlled, physiological programmed cell death, autophagy was demonstrated to be more pronounced during embryonic development and tissue remodeling. ${ }^{75}$ One study suggests that autophagy is a caspase-independent, genetically controlled cell death. ${ }^{76}$ Visualization of autophagic vesicles by electron microscopy is still the golden standard to demonstrate that autophagy is taking place. The electrophoretic mobility change of LC3 from the nonautophagic, cytosolic form (LC3-I; $16 \mathrm{kDa}$ ) to the autophagic, membrane- recruited form (LC3-II; $14 \mathrm{kDa}$ ) provides the first molecular marker-based method for detection of autophagic activity. ${ }^{26,77-79}$ The notion that autophagy is involved in tissue remodeling is in agreement with our finding that the basal levels of LC3-II in normal control animals was 2.5 times higher in the immature than in the adult brains. After $\mathrm{HI}$, increased LC3-II levels were detected as early as $8 \mathrm{~h}$, much more pronounced after 24 and $72 \mathrm{~h}$. This indicates that autophagy is involved in delayed cell death. Notably, a recent EM study demonstrated numerous vacuoles in degenerating neurons after neonatal HI. ${ }^{80}$ Even though the basal levels of LC3-II were higher in the immature brains, the increase after $\mathrm{HI}$ was more pronounced in the adult brains. After HI, LC3-II levels increased about 2.5 times more in P60 animals than in P5 mice, comparing the ipsi- and contralateral hemispheres. The increase was even higher (more than three times) when comparing with the control brains instead of the contralateral hemispheres. Our results show for the first time that autophagy is involved in cell death after cerebral ischemia, and that the activation, as judged by the recruitment of LC3-II, was three times more pronounced in the adult brains compared with the immature brains. 

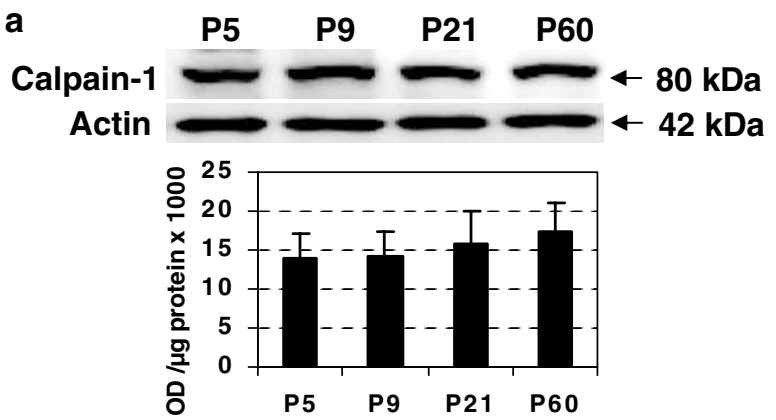

b

$\frac{\mathrm{P5}}{\mathrm{CL} I L} \frac{\mathrm{P} 9}{\mathrm{CL} I L} \frac{\mathrm{P} 21}{\mathrm{CL} I L} \frac{\mathrm{P} 60}{\mathrm{CL} I L}$

Calpain-1

CL IL CL IL CL IL CL IL

Actin $-0-\infty-\infty 42 \mathrm{kDa}$
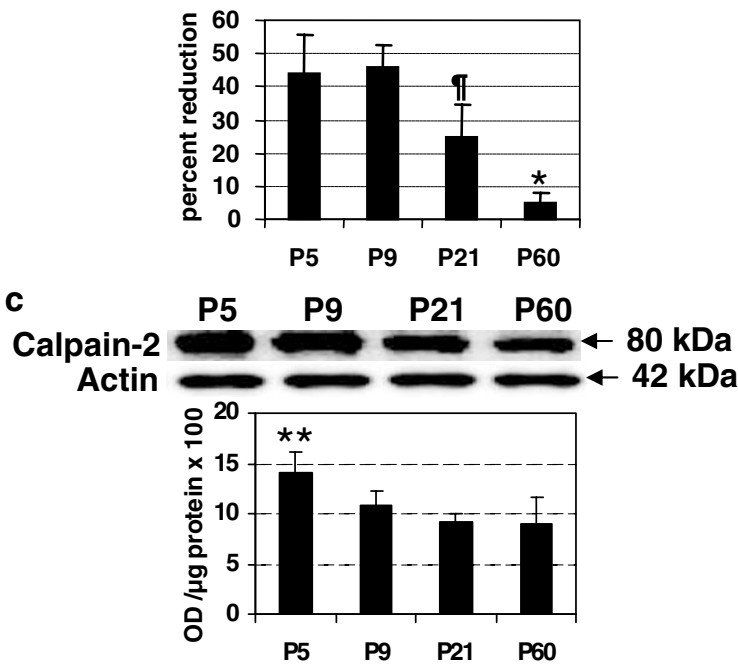

d

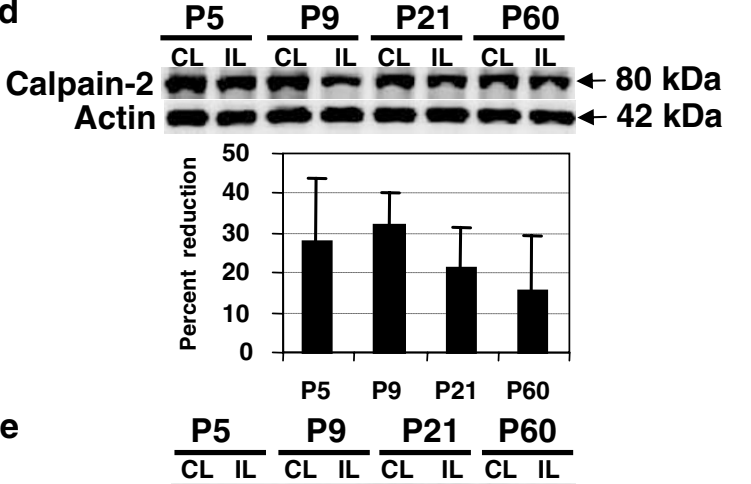

Fodrin $-\cdots=-\square=--4240 \mathrm{kDa}$ ㄷำ $\begin{array}{r}150 \mathrm{kDa} \\ 4145 \mathrm{kDa}\end{array}$ Actin -20 f

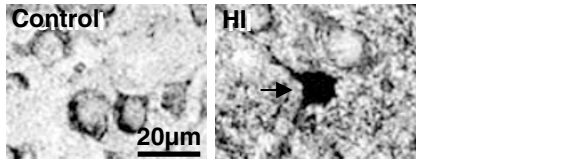

In summary, the sensitivity of neurons, and various brain regions, to injury varies with the animal's age and level of brain development. By adjusting the duration of $\mathrm{HI}$ in different age groups, we could produce a similar extent of overall brain damage. The most obvious developmental difference in the response to $\mathrm{HI}$ was that apoptotic mechanisms, both caspase-dependent and caspase-independent, were activated to a much greater extent in the immature brains compared with the juvenile and adult brains. Despite the constant levels of AIF during brain development, mitochondrial release and nuclear translocation of AIF was much more pronounced in the immature than the juvenile and adult brains. To our knowledge, this is the first report of developmental differences in AIF activation in a model of brain injury. AIF, Cyt $c$ and caspase- 3 are more important in the immature brain than in older animals. Calpains and NO are both important in necrotic, and to some degree, apoptotic cell death, but displayed no obvious developmental differences. Autophagy, as judged by the recruitment of LC3-II, after HI was more pronounced in the adult than in the immature brain. Taken together, our findings offer additional support for the fact that prevention and treatment of brain injury need to be adjusted to the developmental level.

\section{Materials and Methods}

\section{Induction of $\mathrm{HI}$}

Unilateral HI was induced in C57/BL6 male mice on postnatal day 5 (P5), P9, P21 and P60 essentially according to the Rice-Vannucci model. ${ }^{7,81}$ Mice were anesthetized with halothane (3.0\% for induction and $1.0-1.5 \%$ for maintenance) in a mixture of nitrous oxide and oxygen (1:1), and the duration of anesthesia was $<5 \mathrm{~min}$. The left common carotid artery was cut between double ligatures of prolene sutures (6-0). After surgery, the wounds were infiltrated with a local anesthetic, and the pups were allowed to recover for $1-1.5 \mathrm{~h}$. The litters were placed in a chamber perfused with a humidified gas mixture (10\% oxygen in nitrogen) for $65 \mathrm{~min}$ (P5), $60 \mathrm{~min}$ $(\mathrm{P} 9), 50 \mathrm{~min}$ (P21) or $40 \mathrm{~min}$ (P60). The temperature in the incubator, and the temperature of the water used to humidify the gas mixture, was kept at $36^{\circ} \mathrm{C}$. After hypoxic exposure, the pups were returned to their biological

Figure 8 Calpain activation after HI. (a) Immunoblots of homogenates from control mice showed that the protein levels of calpain 1 (large subunit, $80 \mathrm{kDa}$ ) changed very little during development. (b) The $80 \mathrm{kDa}$ large subunit was lost after $\mathrm{HI}$ in the ipsilateral (IL) hemispheres, compared with the contralateral $(\mathrm{CL})$ hemisphere, but the reduction was more pronounced in $\mathrm{P} 5$ and $\mathrm{P} 9$ mice than that in P21 and P60 mice ${ }^{*} P<0.05$ compared with P5, P9 and P21; $P<0.05$ compared with P5 and P9). (c) Immunoblots of calpain 2 ( $80 \mathrm{kDa}$ large subunit) in normal homogenates demonstrated a somewhat higher level in P5 brains $\left({ }^{* \star} P<0.05\right.$ compared with P21 and P60). (d) After HI, the $80 \mathrm{kDa}$ band was partly depleted in the ipsilateral (IL) hemispheres, and the reduction was about the same at all ages. (e) Immunoblots of homogenate samples stained with an antibody against fodrin showed that the levels of intact, $240 \mathrm{kDa}$ fodrin increased during development, as demonstrated in the contralateral $(\mathrm{CL})$ hemispheres. A $150 \mathrm{kDa}$ calpain-specific fodrin breakdown product (FBDP) was detected only in the ipsilateral hemispheres at $24 \mathrm{~h}$ post-HI. The $120 \mathrm{kDa}$ caspase-3-specific breakdown product was detected only in the immature brains. The actin staining on the same membrane verified equal loading for the Western blots $(\mathbf{a}-\mathbf{e})$. (f) Representative stainings of control and postischemic (HI) tissue using an FBDPspecific antibody. An immunopositive cell is indicated by an arrow in the right panel. $\mathrm{Bar}=20 \mu \mathrm{m}$ 

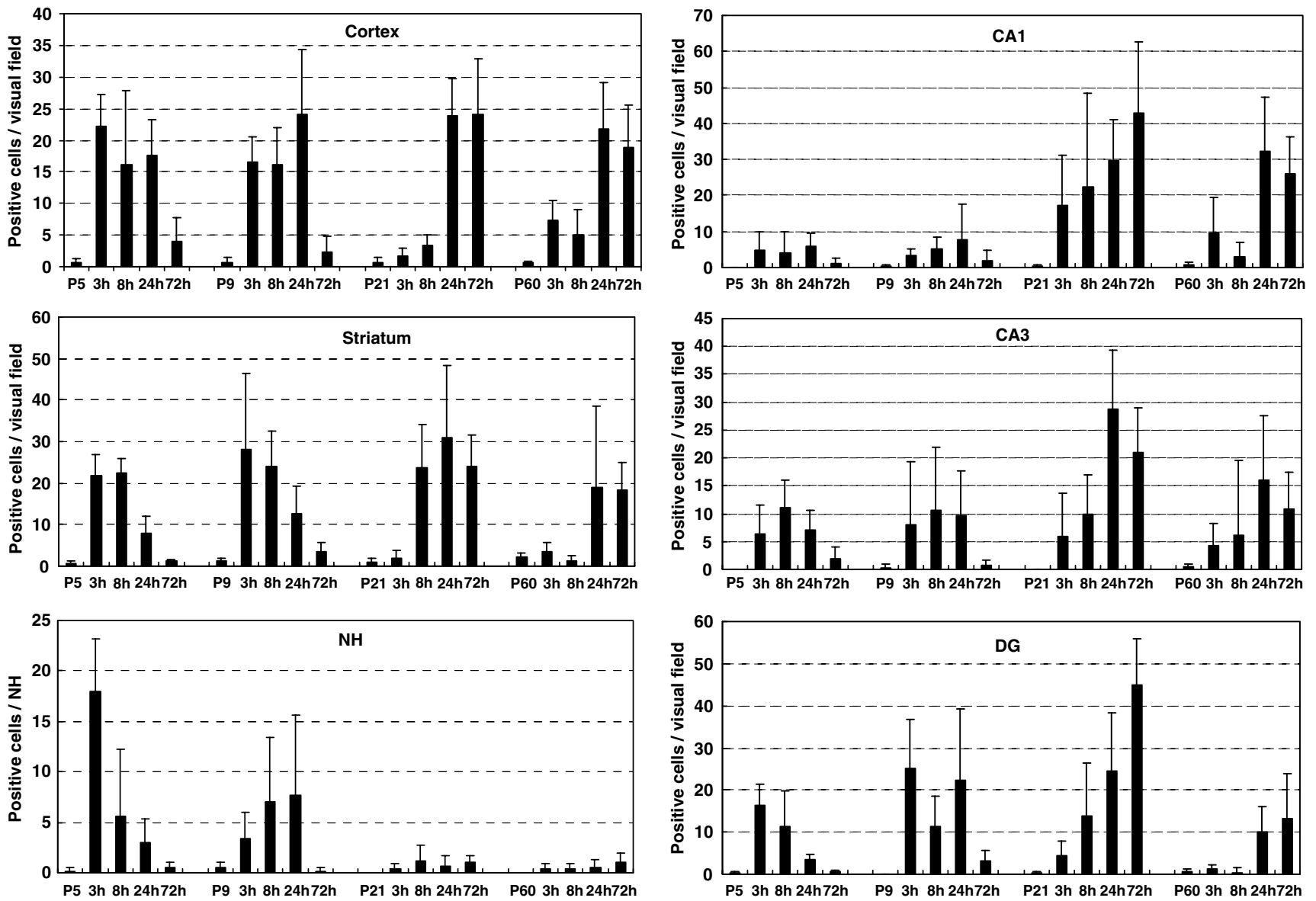

Figure 9 Counts of FBDP-positive cells in the ipsilateral hemisphere after HI. FBDP-positive cells were counted in six different regions as in Figures 3,5 and 7 . In the cortex, the number of FBDP-positive cells had increased to a high level by $3 \mathrm{~h}$ post-Hl and decreased by $72 \mathrm{~h}$ after the insult in the young animals (P5, P9). For the P21 and P60 animals, however, the number of positive cells increased later, peaking by $24 \mathrm{~h}$ and still being elevated at $72 \mathrm{~h}$ post-HI. A similar pattern was seen in the striatum. Again, the lack of immunopositive cells in the NH in the P21 and P60 mice reflected the resistance to injury. The appearance of FBDP-positive cells in all the subfields of the hippocampus after $\mathrm{HI}$ was similar to that in the cortex, but there were more positive cells in P21 and P60 animals than in the younger P9 animals. This difference was particularly obvious in the CA1

dams and were allowed to recover for $3,8,24$ or $72 \mathrm{~h}$. The injury was evaluated at $72 \mathrm{~h}$ post-HI through neuropathological scoring and measurement of tissue volume loss. Control pups, subjected to neither ligation nor hypoxia, were killed at postnatal day 5, 9, 21 or 60 . All animal experimentation was approved by the Ethical Committee of Göteborg (942003).

\section{Sample preparation for immunoblotting and activity assay}

Animals were killed by decapitation $24 \mathrm{~h}$ after $\mathrm{HI}(n=5$ for each age). Control animals were killed on postnatal day $6,10,22$ or 61 ( $n=5$ for each age). The brains were rapidly dissected out on a bed of ice. Parietal cortex was dissected out by first removing the frontal and occipital poles (approx. $2-3 \mathrm{~mm}$ ) of the brain, and second, after positioning the brain with the occipital pole face down on the dissection tray, removing the diencephalon, the medial cortex and the ventrolateral (piriform) cortex, leaving an approximately $50 \mathrm{mg}$ piece of parietal cortex. This piece was dissected out from each hemisphere and 9 volumes of ice-cold homogenization buffer was added $(15 \mathrm{mM}$ Tris- $\mathrm{HCl}, \mathrm{pH} 7.6,320 \mathrm{mM}$ sucrose, $1 \mathrm{mM}$ dithiothretitol, $1 \mathrm{mM} \mathrm{MgCl} 2,0.5 \%$ protease inhibitor cocktail (P8340, Sigma) and $3 \mathrm{mM}$ EDTA-K). Homogenization was performed gently by hand in a 2-ml glass/glass homogenizer. Half of the homogenate was sonicated and used for Western blotting. The other half of the homogenate was centrifuged at $800 \times g$ for $10 \mathrm{~min}$ at $4^{\circ} \mathrm{C}$. The supernatant was then centrifuged at $9200 \times g$ for $15 \mathrm{~min}$ at $4^{\circ} \mathrm{C}$, producing a crude cytosolic fraction in the supernatant (S2), subsequently used for the caspase-3 activity assay. The pellet (P2), enriched in mitochondria, was washed, recentrifuged and used for Western blotting.

\section{Immunohistochemistry}

Mice were deeply anesthetized with $50 \mathrm{mg} / \mathrm{ml}$ phenobarbital and their brains were perfusion-fixed with $5 \%$ formaldehyde in $0.1 \mathrm{M}$ phosphate buffer through the ascending aorta for $5 \mathrm{~min}$. The brains were rapidly removed and immersion-fixed at $4^{\circ} \mathrm{C}$ for $24 \mathrm{~h}$. The brains were dehydrated with xylene and graded ethanol, paraffin-embedded, serial-cut into $5 \mu \mathrm{m}$ sections and mounted on glass slides. Antigen retrieval was performed by boiling deparaffinized sections in $10 \mathrm{mM}$ sodium citrate 

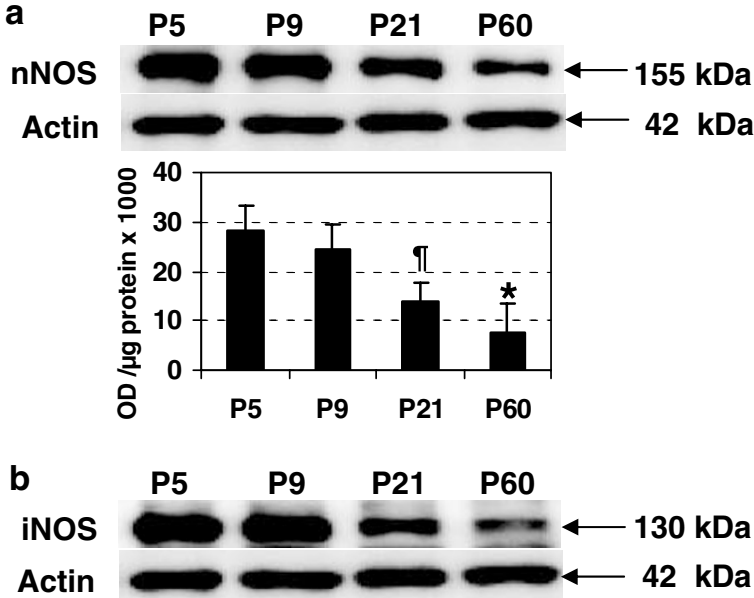

Actin

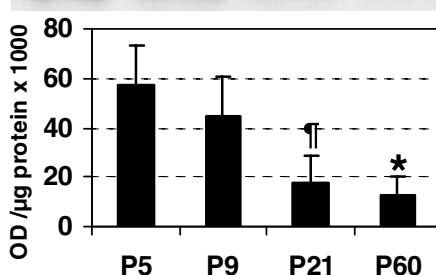

C

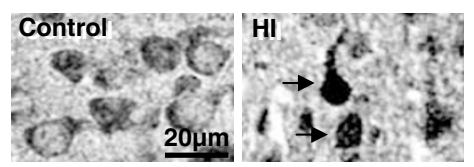

Figure 10 Developmental regulation of NOS. (a and b) Representative immunoblots of brain homogenate samples stained with an antibody against neuronal nitric oxide synthase (nNOS; $155 \mathrm{kDa}$ ) or inducible NOS (iNOS; $130 \mathrm{kDa}$ ), demonstrating a continuous decrease during development. Densitometric quantification revealed that the P5 brains had three times higher levels of nNOS and iNOS than adult ones $\left({ }^{\star} P<0.01\right.$ and $-P<0.05$ compared with $\mathrm{P} 5$ and P9). The actin staining on the same membrane verified equal loading. (c) Representative stainings of control and postischemic (HI) tissue using an antibody against NOS-dependent, peroxynitrite-mediated nitrotyrosine. Two immunopositive cells are indicated by arrows in the right panel. Bar $=20 \mu \mathrm{m}$

buffer ( $\mathrm{pH} \mathrm{6.0)}$ for $10 \mathrm{~min}$. Nonspecific binding was blocked for $30 \mathrm{~min}$ with $4 \%$ horse serum (for MAP-2, Cyt $c$ and AIF) or goat serum (for active caspase-3, fodrin breakdown product (FBDP) and nitrotyrosine) in phosphate-buffered saline (PBS). Anti-MAP-2 (clone HM-2, Sigma), diluted $1: 2000(4 \mu \mathrm{g} / \mathrm{ml})$ in PBS, anti-Cyt $c$ (clone $7 \mathrm{H} 8.2 \mathrm{C} 12$, Pharmingen, San Diego, CA, USA), diluted 1:500 $(2 \mu \mathrm{g} / \mathrm{ml})$ in PBS, anti-AIF (sc-9416, from Santa Cruz Biotechnology, Santa Cruz, CA, USA), diluted $1: 100(2 \mu \mathrm{g} / \mathrm{ml})$, antiactive caspase-3 (67342A, Pharmingen, San Diego, CA, USA), diluted 1:50 $(10 \mu \mathrm{g} / \mathrm{ml})$ in PBS, anti$\operatorname{FBDP}^{82}(1: 50)$ and anti-nitrotyrosine (A-21285, Molecular probes, Eugene, OR, USA), diluted 1: $100(10 \mu \mathrm{g} / \mathrm{ml})$ in PBS were incubated for $60 \mathrm{~min}$ at room temperature, followed by another $60 \mathrm{~min}$ with a biotinylated horse anti-mouse IgG $(2 \mu \mathrm{g} / \mathrm{ml})$ or horse anti-goat $\operatorname{lgG}(2 \mu \mathrm{g} / \mathrm{ml})$ or goat anti-rabbit IgG $(2 \mu \mathrm{g} / \mathrm{ml})$ diluted in PBS. Endogenous peroxidase activity was blocked with $3 \% \mathrm{H}_{2} \mathrm{O}_{2}$ in PBS for 5 min. Visualization was performed

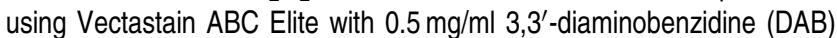
enhanced with $15 \mathrm{mg} / \mathrm{ml}$ ammonium nickel sulfate, $2 \mathrm{mg} / \mathrm{ml}$ beta-Dglucose, $0.4 \mathrm{mg} / \mathrm{ml}$ ammonium chloride and $0.01 \mathrm{mg} / \mathrm{ml}$ beta-glucose oxidase (Sigma).

\section{Immunoblotting}

The protein concentration was determined according to Whitaker and Granum $^{83}$ adapted for microplates, using a Spectramax Plus plate reader (Molecular Devices, Sunnyvale, CA, USA). The samples were mixed with an equal volume of concentrated $(3 \times)$ SDS-PAGE buffer and heated $\left(96^{\circ} \mathrm{C}\right)$ for $5 \mathrm{~min}$. Homogenates (50 $\mu \mathrm{g}$ protein) were run on $4-20 \%$ TrisGlycine gels (Novex) and transferred to reinforced nitrocellulose (Schleicher \& Schuell) membranes. The membranes were blocked in $30 \mathrm{mM}$ Tris- $\mathrm{HCl}(\mathrm{pH} 7.5), 100 \mathrm{mM} \mathrm{NaCl}$ and $0.1 \%$ Tween 20 (TBS-T) containing $5 \%$ fat-free milk powder for $60 \mathrm{~min}$ at room temperature. After washing in TBS-T, the membranes were incubated with anti-AIF (sc-9416, 1: $1000,0.2 \mu \mathrm{g} / \mathrm{ml}$, goat polyclonal antibody, Santa Cruz, CA, USA), anticaspase-3 (H-277, 1:1000, Santa Cruz, CA, USA), anti- Cyt $c(1: 500$, clone 7H8.2C12, Pharmingen, San Diego, CA, USA), anti-calpain 1 (also called $\mu$-calpain) $(1: 1000,1 \mu \mathrm{g} / \mathrm{ml}$, rabbit polyclonal antibody, RP1calpain-1, Triple Point Biologics, Forest Grove, OR, USA), anti-calpain 2 (also called m-calpain) $(1: 1000,1 \mu \mathrm{g} / \mathrm{ml}$, rabbit polyclonal antibody, RP1calpain-2, Triple Point Biologics, Forest Grove, OR,USA), anti-alpha-fodrin (FG6090,1:500, Affiniti Research Product Ltd, Mamhead, UK), antinNOS (clone 16, 1:1000, $0.25 \mu \mathrm{g} / \mathrm{ml}$, BD Biosciences, San Jose, CA, USA), anti-iNOS (sc-650, 1:1000, $0.2 \mu \mathrm{g} / \mathrm{ml}$, rabbit polyclonal antibody, Santa Cruz, CA, USA) anti-LC3 $(1: 800)^{79}$ and anti-actin (A2066, $1: 200$, Sigma, Stockholm, Sweden) at $4^{\circ} \mathrm{C}$ overnight. After washing, the membranes were incubated with a peroxidase-labeled secondary antibody for $30 \mathrm{~min}$ at room temperature (goat anti-rabbit, $1: 2000$, horse anti-goat, $1: 2000$, or horse anti-mouse $1: 4000)$. Immunoreactive species were visualized using the Super Signal Western Dura substrate (Pierce, Rockford, IL, USA) and a LAS 1000 cooled CCD camera (Fujifilm, Tokyo, Japan). Immunoreative bands were quantified using the Image Gauge software (Fujifilm, Tokyo, Japan).

\section{Caspase activity assays}

The protein concentrations were determined as above. Samples of crude cytosolic fractions (S2) $(25 \mu \mathrm{l})$ were mixed with $75 \mu \mathrm{l}$ of extraction buffer as described earlier. ${ }^{23}$ Cleavage of Ac-DEVD-AMC (Peptide Institute, Osaka, Japan) was measured with an excitation wavelength of $380 \mathrm{~nm}$ and an emission wavelength of $460 \mathrm{~nm}$, and expressed as pmol AMC released per $\mathrm{mg}$ protein and minute.

\section{Injury evaluation}

\section{Neuropathological scoring}

Brain injury in different regions was evaluated using a semiquantitative neuropathological scoring system as described earlier. ${ }^{84}$ Briefly, sections were stained with thionin/acid fuchsin and scored by an observer blinded to the animals. The cortical injury was graded from 0 to 4,0 being no observable injury and 4 confluent infarction encompassing most of the cerebral cortex. The damage in the hippocampus, striatum and thalamus was assessed both with respect to hypotrophy (shrinkage) (0-3) and observable cell injury/infraction (0-3) resulting in a neuropathological score for each brain region (0-6). The total score $(0-22)$ was the sum of the scores for all four regions.

\section{Tissue volume}

The volumes of tissue loss were measured 3 days post-HI by sectioning the entire brains into $5 \mu \mathrm{m}$ sections and staining every 100th section for MAP-2. The areas in the cortex, striatum, thalamus and hypothalamus 

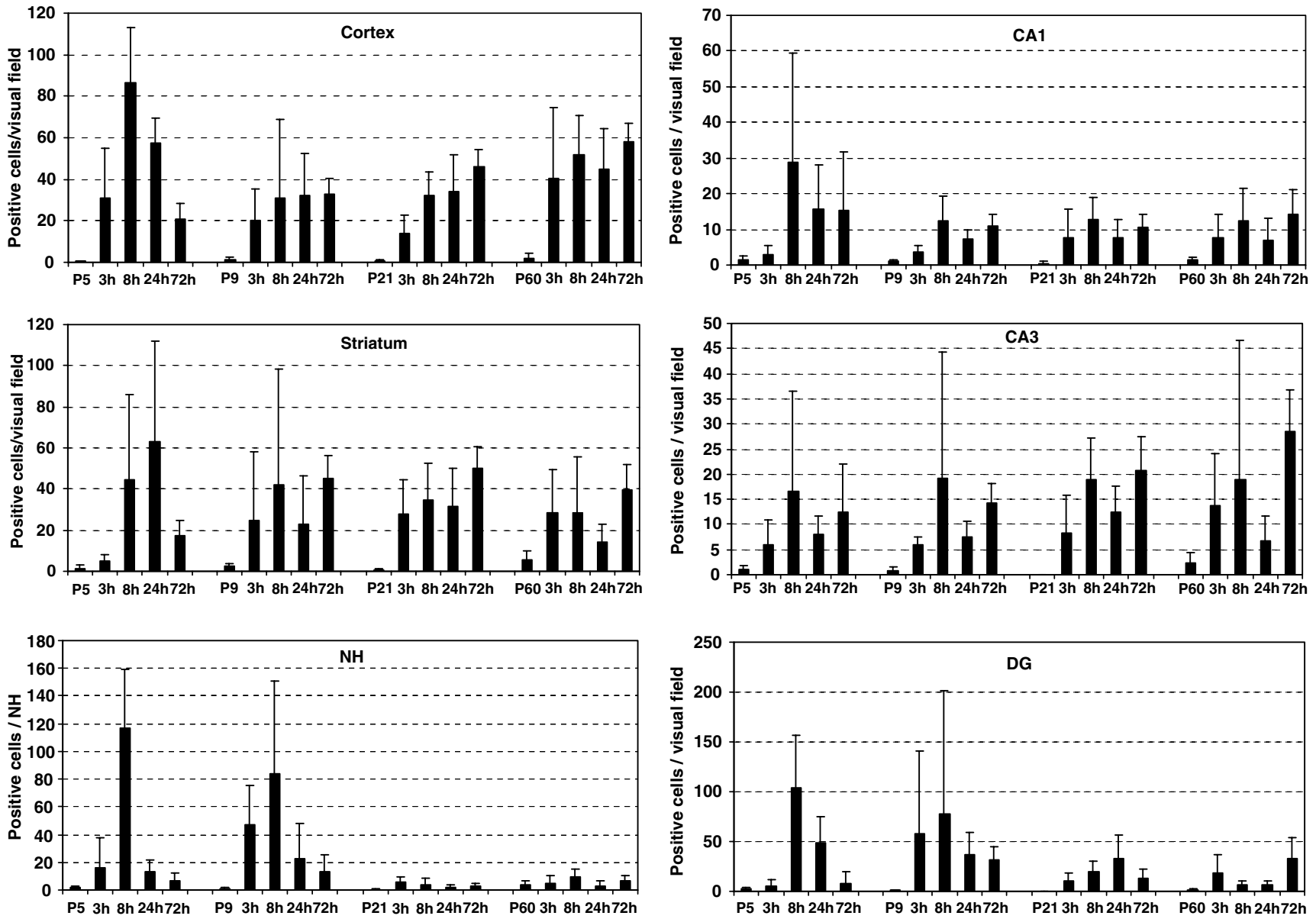

Figure 11 Counts of nitrotyrosine-positive cells in the ipsilateral hemisphere after HI. Nitrotyrosine-positive cells were counted in six different regions as in Figures 3,5 , 7 and 9. Nitrotyrosine-positive cells increased early during reperfusion and reached a peak around $8 \mathrm{~h}$ after HI. In P5 brains, the numbers decreased thereafter, but in P960 mice the numbers remained on a high level at least until $72 \mathrm{~h}$ post-HI. As in the case of the other injury markers, the NH did not display any nitrotyrosine-positive cells in the P21 and P60 mice, reflecting the resistance to injury at these ages. Overall, the total number of nitrotyrosine-positive cells was not so much different between the different ages except in the DG where the P5 and P9 brains displayed a higher number of immunopositive cells

displaying MAP-2 staining were measured in both hemispheres using Micro Image (Olympus, Japan) and the volumes calculated according to the Cavalieri Principle using the following formula: $V=\sum A P T$, where $V=$ total volume, $\sum A$ is the sum of the areas measured, $P=$ the inverse of the sampling fraction and $T$ is the section thickness. ${ }^{85}$ The ratio of tissue loss $=$ (contralateral volume-ipsilateral volume)/contralateral volume.

\section{Cell counting}

Cell counting was performed in the cortex, hippocampus, striatum and thalamus $(\mathrm{NH})$ in the similar level for different ages (according to Bregma: $-1.64 \mathrm{~mm}$ of P60, Franklin and Paxinos). The hippocampus was divided into the CA1, CA3 and DG subfields. Positive cells were counted at $\times 400$ magnification (one visual field $=0.196 \mathrm{~mm}^{2}$ ). In the cortex, three visual fields within an area displaying loss of MAP-2 (if any) were counted and expressed as average number per visual field. Parallel sections were used for all different staining. The counting results were corrected for possible differences in cellular density at different ages by expressing the results as number of immunopositive cells per total number of cells in the visual field or area counted.

\section{Statistics}

The Mann-Whitney U-test with Bonferroni correction, preceded by a Kruskal-Wallis test when comparing more than two groups, was used when comparing injury scores and tissue loss. ANOVA with Fisher's post hoc test was used when comparing quantification of Western blots and activity assay. Significance level was assigned at $P<0.05$.

\section{Acknowledgements}

This work was supported by the Swedish Research Council (to $\mathrm{HH}$ and $\mathrm{KB}$ ), the Swedish Child Cancer Foundation (Barncancerfonden) (to KB), the Göteborg Medical Society, the Åhlén Foundation, the Swedish Society of Medicine, the Wilhelm and Martina Lundgren Foundation, the Sven Jerring Foundation, the Frimurare Barnhus Foundation, the Magnus Bergvall Foundation, the National Natural Science Foundation of China (to 
4. Yager JY, Shuaib A and Thornhill J (1996) The effect of age on susceptibility to brain damage in a model of global hemispheric hypoxia-ischemia. Brain Res. Dev. Brain Res. 93: 143-154

5. Sutherland GR, Dix GA and Auer RN (1996) Effect of age in rodent models of focal and forebrain ischemia. Stroke. 27: 1663-1667; discussion 1668

6. Papadopoulos MC, Koumenis IL, Yuan TY and Giffard RG (1998) Increasing vulnerability of astrocytes to oxidative injury with age despite constant antioxidant defenses. Neuroscience. 82: 915-925

7. Rice III JE, Vannucci RC and Brierley JB (1981) The influence of immaturity on hypoxic-ischemic brain damage in the rat. Ann. Neurol. 9: 131-141

8. McDonald JW, Silverstein FS and Johnston MV (1988) Neurotoxicity of $N$ methyl-D-aspartate is markedly enhanced in developing rat central nervous system. Brain Res. 459: 200-203

9. Ikonomidou C, Mosinger JL, Salles KS, Labruyere J and Olney JW (1989) Sensitivity of the developing rat brain to hypobaric/ischemic damage parallels sensitivity to $\mathrm{N}$-methyl-aspartate neurotoxicity. J. Neurosci. 9: 2809-2818

b
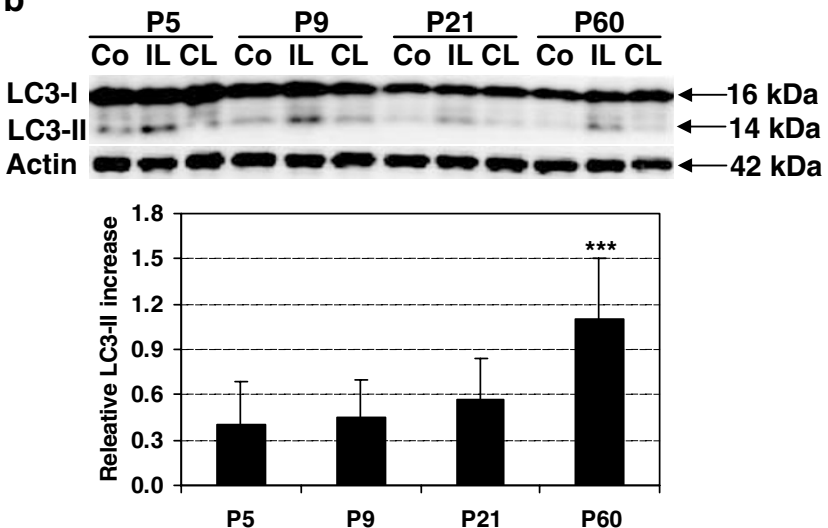

Figure 12 Immunoblot analysis of LC3-I and the autophagy marker LC3-II. (a) Representative immunoblots of normal brain homogenates demonstrating the presence of the two forms of LC3, LC3-I (16 kDa) and LC3-II (14 kDa) at all ages. The lower panel shows the results of densitometric quantification $(n=5$ per group; average \pm S.D.), demonstrating that both LC3-I and LC3-II decreased approximately $50 \%$ in control brains from P5 to $\mathrm{P} 60\left(\widetilde{\top} P<0.05,{ }^{*} P<0.05\right.$, ${ }^{* *} P<0.01$, compared with $P 5$ ). (b) The upper panel shows representative immunoblots of brain homogenates from control mice (Co), from ipsilateral hemispheres (IL) and contralateral hemispheres $(\mathrm{CL})$, demonstrating an increased appearance of the LC3-II band in the ipsilateral hemispheres $24 \mathrm{~h}$ post-HI. The relative increase of LC3-II was calculated based on the optical density (OD) of the different bands in individual animals according to the formula: (OD of the ipsilateral $-O D$ of the contralateral)/OD of the contralateral. LC3-II was almost three times higher in the adult (P60) brains compared with immature (P5) brains ${ }^{* * *} P<0.0001$ compared with P5, P9 and P21). The actin staining on the same membrane verified equal loading for the Western blots

CZ, 30470598), the Bureau of Science and Technology of Henan Province, the Department of Education of Henan Province.

\section{References}

1. Hu BR, Liu CL, Ouyang Y, Blomgren $\mathrm{K}$ and Siesjo BK (2000) Involvement of caspase-3 in cell death after hypoxia-ischemia declines during brain maturation. J. Cereb. Blood Flow Metab. 20: 1294-1300

2. Romero AA, Gross SR, Cheng KY, Goldsmith NK and Geller HM (2003) An age-related increase in resistance to DNA damage-induced apoptotic cell death is associated with development of DNA repair mechanisms. J. Neurochem. 84: 1275-1287

3. Towfighi J, Mauger D, Vannucci RC and Vannucci SJ (1997) Influence of age on the cerebral lesions in an immature rat model of cerebral hypoxia-ischemia: a light microscopic study. Brain Res. Dev. Brain Res. 100: 149-160
10. Adelson PD and Kochanek PM (1998) Head injury in children. J. Child Neurol. 13: $2-15$

11. Martin LJ, Al-Abdulla NA, Brambrink AM, Kirsch JR, Sieber FE and PorteraCailliau C (1998) Neurodegeneration in excitotoxicity, global cerebral ischemia, and target deprivation: a perspective on the contributions of apoptosis and necrosis. Brain Res. Bull. 46: 281-309

12. Northington FJ, Ferriero DM, Graham EM, Traystman RJ and Martin LJ (2001) Early neurodegeneration after hypoxia-ischemia in neonatal rat is necrosis while delayed neuronal death is apoptosis. Neurobiol. Dis. 8: 207-219

13. Yakovlev AG and Faden Al (2004) Mechanisms of neural cell death: implications for development of neuroprotective treatment strategies. NeuroRx. 1: $5-16$

14. Liu CL, Siesjo BK and Hu BR (2004) Pathogenesis of hippocampal neuronal death after hypoxia-ischemia changes during brain development. Neuroscience 127: 113-123

15. Raff MC, Barres BA, Burne JF, Coles HS, Ishizaki Y and Jacobson MD (1993) Programmed cell death and the control of cell survival: lessons from the nervous system. Science 262: 695-700

16. Blomgren $\mathrm{K}$, Zhu C, Wang X, Karlsson JO, Leverin AL, Bahr BA, Mallard C and Hagberg $H$ (2001) Synergistic activation of caspase-3 by m-calpain after neonatal hypoxia-ischemia: a mechanism of 'pathological apoptosis'? J. Biol.

17. Ota K, Yakovlev AG, Itaya A, Kameoka M, Tanaka Y and Yoshihara K (2002) Alteration of apoptotic protease-activating factor-1 (APAF-1)-dependent apoptotic pathway during development of rat brain and liver. J. Biochem. (Tokyo). 131: 131-135

18. Vekrellis K, McCarthy MJ, Watson A, Whittield J, Rubin LL and Ham J (1997) Bax promotes neuronal cell death and is downregulated during the development of the nervous system. Development 124: 1239-1249

19. Merry DE, Veis DJ, Hickey WF and Korsmeyer SJ (1994) bcl-2 protein expression is widespread in the developing nervous system and retained in the adult PNS. Development 120: 301-311

20. Ikonomidou C, Bosch F, Miksa M, Bittigau P, Vockler J, Dikranian K, Tenkova TI, Stefovska V, Turski L and Olney JW (1999) Blockade of NMDA receptors and apoptotic neurodegeneration in the developing brain. Science 283: 70-74

21. Zhu C, Wang X, Hagberg H and Blomgren K (2000) Correlation between caspase-3 activation and three different markers of DNA damage in neonatal cerebral hypoxia-ischemia. J. Neurochem. 75: 819-829

22. Lesuisse $C$ and Martin LJ (2002) Immature and mature cortical neurons engage different apoptotic mechanisms involving caspase- 3 and the mitogen-activated protein kinase pathway. J. Cereb. Blood Flow Metab. 22: 935-950

23. Wang X, Karlsson JO, Zhu C, Bahr BA, Hagberg H and Blomgren K (2001) Caspase-3 activation after neonatal rat cerebral hypoxia-ischemia. Biol. Neonate. 79: 172-179

24. Cheng Y, Deshmukh M, D'Costa A, Demaro JA, Gidday JM, Shah A, Sun Y, Jacquin MF, Johnson EM and Holtzman DM (1998) Caspase inhibitor affords neuroprotection with delayed administration in a rat model of neonatal hypoxicischemic brain injury. J. Clin. Invest. 101: 1992-1999

25. Wang $X$, Zhu $C$, Hagberg $H$, Korhonen L, Sandberg M, Lindholm D and Blomgren K (2004) X-linked inhibitor of apoptosis (XIAP) protein protects against caspase activation and tissue loss after neonatal hypoxia-ischemia. Neurobiol. Dis. 16: 179-189 Chem. 276: 10191-10198 
26. Kabeya Y, Mizushima N, Ueno T, Yamamoto A, Kirisako T, Noda T, Kominami E, Ohsumi Y and Yoshimori T (2000) LC3, a mammalian homologue of yeast Apg8p, is localized in autophagosome membranes after processing. EMBO J. 19: $5720-5728$

27. Gill R, Soriano M, Blomgren K, Hagberg H, Wybrecht R, Miss MT, Hoefer S, Adam G, Niederhauser O, Kemp JA and Loetscher H (2002) Role of caspase-3 activation in cerebral ischemia-induced neurodegeneration in adult and neonatal brain. J. Cereb. Blood Flow Metab. 22: 420-430

28. Sidhu RS, Tuor UI and Del Bigio MR (1997) Nuclear condensation and fragmentation following cerebral hypoxia-ischemia occurs more frequently in immature than older rats. Neurosci. Lett. 223: 129-132

29. Cheng Y, Gidday JM, Yan Q, Shah AR and Holtzman DM (1997) Marked agedependent neuroprotection by brain-derived neurotrophic factor against neonatal hypoxic-ischemic brain injury. Ann Neurol. 41: 521-529

30. Tuor UI, Chumas PD and Del Bigio MR (1995) Prevention of hypoxic-ischemic damage with dexamethasone is dependent on age and not influenced by fasting. Exp. Neurol. 132: 116-122

31. Wang X, Zhu C, Qiu L, Hagberg H, Sandberg M and Blomgren K (2003) Activation of ERK $1 / 2$ after neonatal rat cerebral hypoxia-ischaemia. J. Neurochem. 86: 351-362

32. Zhu C, Qiu L, Wang X, Hallin U, Cande C, Kroemer G, Hagberg H and Blomgren K (2003) Involvement of apoptosis-inducing factor in neuronal death after hypoxia-ischemia in the neonatal rat brain. J. Neurochem. 86: 306-317

33. Plesnila N, Zhu C, Culmsee C, Groger M, Moskowitz MA and Blomgren K (2004) Nuclear translocation of apoptosis-inducing factor after focal cerebral ischemia. J. Cereb. Blood Flow Metab. 24: 458-466

34. Fukuda H, Fukuda A, Zhu C, Korhonen L, Swanpalmer J, Hertzman S, Leist M, Lannering B, Lindholm D, Bjork-Eriksson T, Marky I and Blomgren K (2004) Irradiation-induced progenitor cell death in the developing brain is resistant to erythropoietin treatment and caspase inhibition. Cell Death Differ. 11: 1166-1178

35. Blomgren K, Hallin U, Andersson AL, Puka-Sundvall M, Bahr BA, McRae A, Saido TC, Kawashima S and Hagberg H (1999) Calpastatin is up-regulated in response to hypoxia and is a suicide substrate to calpain after neonatal cerebral hypoxia-ischemia. J. Biol. Chem. 274: 14046-14052

36. Blomgren K, Kawashima S, Saido TC, Karlsson JO, Elmered A and Hagberg H (1995) Fodrin degradation and subcellular distribution of calpains after neonatal rat cerebral hypoxic-ischemia. Brain Res. 684: 143-149

37. Blomgren K, McRae A, Bona E, Saido TC, Karlsson JO and Hagberg H (1995) Degradation of fodrin and MAP 2 after neonatal cerebral hypoxic-ischemia. Brain Res. 684: 136-142

38. Zhu C, Wang X, Qiu L, Peeters-Scholte C, Hagberg H and Blomgren K (2004) Nitrosylation precedes caspase-3 activation and translocation of apoptosisinducing factor in neonatal rat cerebral hypoxia-ischaemia. J. Neurochem. 90 462-471

39. Duffy TE, Kohle SJ and Vannucci RC (1975) Carbohydrate and energy metabolism in perinatal rat brain: relation to survival in anoxia. J. Neurochem. 24: 271-276

40. Yakovlev AG, Ota K, Wang G, Movsesyan V, Bao WL, Yoshihara K and Faden Al (2001) Differential expression of apoptotic protease-activating factor-1 and caspase-3 genes and susceptibility to apoptosis during brain development and after traumatic brain injury. J. Neurosci. 21: 7439-7446

41. Wang X, Zhu C, Wang X, Gerwien JW, Schratttenholz A, Sandberg M, Leist M and Blomgren K (2004) The non-erythropoietin asialoerythropoietin protects against neonatal hypoxia-ischemia as potently as erythropoietin. J. Neurochem. 91: 900-910

42. Hedtjarn M, Leverin AL, Eriksson K, Blomgren K, Mallard C and Hagberg $\mathrm{H}$ (2002) Interleukin-18 involvement in hypoxic-ischemic brain injury. J. Neurosci. 22: $5910-5919$

43. Bona E, Hagberg H, Loberg EM, Bagenholm R and Thoresen M. (1998) Protective effects of moderate hypothermia after neonatal hypoxia-ischemia: short- and long-term outcome. Pediatr. Res. 43: 738-745

44. Muramatsu K, Fukuda A, Togari H, Wada Y and Nishino H (1997) Vulnerability to cerebral hypoxic-ischemic insult in neonatal but not in adult rats is in parallel with disruption of the blood-brain barrier. Stroke. 28: 2281-2288; discussion 2288-2289

45. Pohl D, Bittigau P, Ishimaru MJ, Stadthaus D, Hubner C, Olney JW, Turski L and Ikonomidou C (1999) N-Methyl-D-aspartate antagonists and apoptotic cell death triggered by head trauma in developing rat brain. Proc. Natl. Acad. Sci. USA. 96: 2508-2513

46. Kalou M, Rauchova H and Drahota Z (2001) Postnatal development of energy metabolism in the rat brain. Physiol. Res. 50: 315-319

47. Zhu C, Wang X, Cheng X, Qiu L, Xu F, Simbruner G and Blomgren K (2004) Post-ischemic hypothermia-induced tissue protection and diminished apoptosis after neonatal cerebral hypoxia-ischemia. Brain Res. 996: 67-75

48. Fujimura M, Morita-Fujimura Y, Kawase M, Copin JC, Calagui B, Epstein CJ and Chan PH (1999) Manganese superoxide dismutase mediates the early release of mitochondrial cytochrome $c$ and subsequent DNA fragmentation after permanent focal cerebral ischemia in mice. J. Neurosci. 19: 3414-3422

49. Luetjens CM, Bui NT, Sengpiel B, Munstermann G, Poppe M, Krohn AJ, Bauerbach E, Krieglstein J and Prehn JH (2000) Delayed mitochondrial dysfunction in excitotoxic neuron death: cytochrome $c$ release and a secondary increase in superoxide production. J. Neurosci. 20: 5715-5723

50. Murphy AN, Fiskum G and Beal MF (1999) Mitochondria in neurodegeneration: bioenergetic function in cell life and death. J. Cereb. Blood Flow Metab. 19: $231-245$

51. Joly LM, Mucignat V, Mariani J, Plotkine M and Charriaut-Marlangue C (2004) Caspase inhibition after neonatal ischemia in the rat brain. J. Cereb. Blood Flow Metab. 24: 124-131

52. Susin SA, Lorenzo HK, Zamzami N, Marzo I, Snow BE, Brothers GM, Mangion J, Jacotot E, Costantini P, Loeffler M, Larochette N, Goodlett DR, Aebersold R, Siderovski DP, Penninger JM and Kroemer G (1999) Molecular characterization of mitochondrial apoptosis-inducing factor. Nature 397: $441-446$

53. Joza N, Susin SA, Daugas E, Stanford WL, Cho SK, Li CY, Sasaki T, Elia AJ, Cheng HY, Ravagnan L, Ferri KF, Zamzami N, Wakeham A, Hakem R, Yoshida $\mathrm{H}$, Kong YY, Mak TW, Zuniga-Pflucker JC, Kroemer G and Penninger JM (2001) Essential role of the mitochondrial apoptosis-inducing factor in programmed cell death. Nature 410: $549-554$

54. Cao G, Clark RS, Pei W, Yin W, Zhang F, Sun FY, Graham SH and Chen J (2003) Translocation of apoptosis-inducing factor in vulnerable neurons after transient cerebral ischemia and in neuronal cultures after oxygen-glucose deprivation. J. Cereb. Blood Flow Metab. 23: $1137-1150$

55. Ferrand-Drake M, Zhu C, Gido G, Hansen AJ, Karlsson JO, Bahr BA, Zamzami $\mathrm{N}$, Kroemer G, Chan PH, Wieloch T and Blomgren K (2003) Cyclosporin A prevents calpain activation despite increased intracellular calcium concentrations, as well as translocation of apoptosis-inducing factor, cytochrome $c$ and caspase-3 activation in neurons exposed to transient hypoglycemia. J. Neurochem. 85: 1431-1442

56. Ekdahl CT, Zhu C, Bonde S, Bahr BA, Blomgren K and Lindvall O (2003) Death mechanisms in status epilepticus-generated neurons and effects of additional seizures on their survival. Neurobiol. Dis. 14: 513-523

57. Zhang X, Chen J, Graham SH, Du L, Kochanek PM, Draviam R, Guo F, Nathaniel PD, Szabo C, Watkins SC and Clark RS (2002) Intranuclear localization of apoptosis-inducing factor (AIF) and large scale DNA fragmentation after traumatic brain injury in rats and in neuronal cultures exposed to peroxynitrite. J. Neurochem. 82: 181-191

58. Zhao H, Yenari MA, Cheng D, Barreto-Chang OL, Sapolsky RM and Steinberg GK (2004) Bcl-2 transfection via herpes simplex virus blocks apoptosisinducing factor translocation after focal ischemia in the rat. J. Cereb. Blood Flow Metab. 24: 681-692

59. Cregan SP, Fortin A, MacLaurin JG, Callaghan SM, Cecconi F, Yu SW, Dawson TM, Dawson VL, Park DS, Kroemer G and Slack RS (2002) Apoptosisinducing factor is involved in the regulation of caspase-independent neuronal cell death. J. Cell Biol. 158: 507-517

60. Yuan CQ, Li YN and Zhang XF (2004) Down-regulation of apoptosis-inducing factor protein by RNA interference inhibits UVA-induced cell death. Biochem. Biophys. Res. Commun. 317: 1108-1113

61. Miramar MD, Costantini P, Ravagnan L, Saraiva LM, Haouzi D, Brothers G, Penninger JM, Peleato ML, Kroemer G and Susin SA (2001) NADH oxidase activity of mitochondrial apoptosis-inducing factor. J. Biol. Chem. 276: $16391-16398$

62. Klein JA, Longo-Guess CM, Rossmann MP, Seburn KL, Hurd RE, Frankel WN, Bronson RT and Ackerman SL (2002) The harlequin mouse mutation downregulates apoptosis-inducing factor. Nature 419: 367-374 
63. Dutta S, Chiu YC, Probert AW and Wang KK (2002) Selective release of calpain produced alphall-spectrin (alpha-fodrin) breakdown products by acute neuronal cell death. Biol. Chem. 383: 785-791

64. Siman R and Noszek JC (1988) Excitatory amino acids activate calpain I and induce structural protein breakdown in vivo. Neuron. 1: 279-287

65. Pang Z, Bondada V, Sengoku T, Siman R and Geddes JW (2003) Calpain facilitates the neuron death induced by 3-nitropropionic acid and contributes to the necrotic morphology. J. Neuropathol. Exp. Neurol. 62: 633-643

66. Saido TC, Yokota M, Nagao S, Yamaura I, Tani E, Tsuchiya T, Suzuki K and Kawashima S (1993) Spatial resolution of fodrin proteolysis in postischemic brain. J. Biol. Chem. 268: 25239-25243

67. Emgard M, Hallin U, Karlsson J, Bahr BA, Brundin P and Blomgren K (2003) Both apoptosis and necrosis occur early after intracerebral grafting of ventral mesencephalic tissue: a role for protease activation. J. Neurochem. 86: 1223-1232

68. Yamashima T, Tonchev AB, Tsukada T, Saido TC, Imajoh-Ohmi S, Momoi T and Kominami E (2003) Sustained calpain activation associated with lysosomal rupture executes necrosis of the postischemic CA1 neurons in primates. Hippocampus. 13: 791-800

69. Cai Z, Hutchins JB and Rhodes PG (1998) Intrauterine hypoxia-ischemia alters nitric oxide synthase expression and activity in fetal and neonatal rat brains. Brain Res. Dev. Brain Res. 109: 265-269

70. Higuchi Y, Hattori H, Kume T, Tsuji M, Akaike A and Furusho K (1998) Increase in nitric oxide in the hypoxic-ischemic neonatal rat brain and suppression by 7 nitroindazole and aminoguanidine. Eur. J. Pharmacol. 342: 47-49

71. Ikeno S, Nagata N, Yoshida S, Takahashi H, Kigawa J and Terakawa N (2000) Immature brain injury via peroxynitrite production induced by inducible nitric oxide synthase after hypoxia-ischemia in rats. J. Obstet. Gynaecol. Res. 26: 227-234

72. Peeters-Scholte C, Koster J, van den Tweel E, Blomgren K, Hamers N, Zhu C, van Buul-Offers S, Hagberg H, van Bel F, Heijnen C and Groenendaal F (2002) Effects of selective nitric oxide synthase inhibition on IGF-1, caspases and cytokines in a newborn piglet model of perinatal hypoxia-ischaemia. Dev. Neurosci. 24: 396-404

73. Andersen JK (2004) Oxidative stress in neurodegeneration: cause or consequence? Nat. Med. 10 (Suppl): S18-S25

74. McQuillen PS and Ferriero DM (2004) Selective vulnerability in the developing central nervous system. Pediatr. Neurol. 30: 227-235
75. Bursch W (2001) The autophagosomal-lysosomal compartment in programmed cell death. Cell Death Differ. 8: 569-581

76. Xue L, Fletcher GC and Tolkovsky AM (1999) Autophagy is activated by apoptotic signalling in sympathetic neurons: an alternative mechanism of death execution. Mol. Cell Neurosci. 14: 180-198

77. Kabeya $Y$, Mizushima N, Yamamoto A, Oshitani-Okamoto S, Ohsumi $Y$ and Yoshimori T (2004) LC3, GABARAP and GATE16 localize to autophagosomal membrane depending on form-II formation. J. Cell Sci. 117 (Part 13): 2805-2812

78. Asanuma K, Tanida I, Shirato I, Ueno T, Takahara H, Nishitani T, Kominami E and Tomino Y (2003) MAP-LC3, a promising autophagosomal marker, is processed during the differentiation and recovery of podocytes from PAN nephrosis. FASEB J. 17: 1165-1167

79. Yu WH, Kumar A, Peterhoff C, Shapiro Kulnane L, Uchiyama Y, Lamb BT, Cuervo AM and Nixon RA (2004) Autophagic vacuoles are enriched in amyloid precursor protein-secretase activities: implications for beta-amyloid peptide over-production and localization in Alzheimer's disease. Int. J. Biochem. Cell Biol. 36: 2531-2540

80. Puka-Sundvall M, Gajkowska B, Cholewinski M, Blomgren K, Lazarewicz JW and Hagberg $\mathrm{H}(2000)$ Subcellular distribution of calcium and ultrastructural changes after cerebral hypoxia-ischemia in immature rats. Brain Res. Dev. Brain Res. 125: 31-41

81. Sheldon RA, Sedik C and Ferriero DM (1998) Strain-related brain injury in neonatal mice subjected to hypoxia-ischemia. Brain Res. 810: 114-122

82. Bahr BA, Tiriveedhi S, Park GY and Lynch G (1995) Induction of calpainmediated spectrin fragments by pathogenic treatments in long-term hippocampal slices. J. Pharmacol. Exp. Ther. 273: 902-908

83. Whitaker JR and Granum PE (1980) An absolute method for protein determination based on difference in absorbance at 235 and $280 \mathrm{~nm}$. Anal. Biochem. 109: 156-159

84. Hagberg H, Wilson MA, Matsushita H, Zhu C, Lange M, Gustavsson M, Poitras MF, Dawson TM, Dawson VL, Northington F and Johnston MV (2004) PARP-1 gene disruption in mice preferentially protects males from perinatal brain injury. J. Neurochem. 90: 1068-1075

85. Mallard EC, Williams CE, Gunn AJ, Gunning Ml and Gluckman PD (1993) Frequent episodes of brief ischemia sensitize the fetal sheep brain to neuronal loss and induce striatal injury. Pediatr. Res. 33: 61-65 